Rhode Island College

Digital Commons @ RIC

\title{
A Systematic Review to Examine the Effectiveness of Antibiotic Educational Programs in Outpatient Settings at Reducing Antibiotic Prescribing?
}

Mathew Reynolds

Follow this and additional works at: https://digitalcommons.ric.edu/etd

Part of the Nursing Commons

\section{Recommended Citation}

Reynolds, Mathew, "A Systematic Review to Examine the Effectiveness of Antibiotic Educational Programs in Outpatient Settings at Reducing Antibiotic Prescribing?" (2020). Master's Theses, Dissertations, Graduate Research and Major Papers Overview. 366.

https://digitalcommons.ric.edu/etd/366

This Major Paper is brought to you for free and open access by the Master's Theses, Dissertations, Graduate Research and Major Papers at Digital Commons @ RIC. It has been accepted for inclusion in Master's Theses, Dissertations, Graduate Research and Major Papers Overview by an authorized administrator of Digital Commons @ RIC. For more information, please contact digitalcommons@ric.edu. 


\title{
A SYSTEMATIC REVIEW TO EXAMINE THE EFFECTIVENESS OF ANTIBIOTIC EDUCATIONAL PROGRAMS IN OUTPATIENT SETTINGS AT REDUCING ANTIBIOTIC PRESCRIBING?
}

by

Matthew Reynolds

\author{
A Major Paper Submitted in Partial Fulfillment \\ of the Requirements for the Degree of \\ Master of Science in Nursing \\ in
}

The School of Nursing

Rhode Island College 


\begin{abstract}
Antibiotic resistance has been identified by both the Center for Disease Control and the World Health Organization as a worldwide epidemic. Antimicrobial stewardship programs have been utilized at inpatient settings that include educational programs about antibiotic resistance. A systematic review was conducted to evaluate the effectiveness of antimicrobial resistance education in outpatient settings. The databases searched were MEDLINE, PubMed, Google Scholar and CINAHL. PRISMA checklist and flow diagram were used for identifying the randomized control trials for the systematic review. A total of five articles were identified and organized using data collection tables. The Critical Appraisal Skills Programme (CASP) checklist was used to assess the quality of the trials. All five of the articles showed improvement in overall antibiotic prescribing with education in an outpatient setting. Limitations to the studies included patient/provider drop-out rates, changing diagnoses to order antibiotics, lack of inclusion of all antibiotics ordered by practices, time of year the studies took place, and provider access to training regardless of being in sample. Implications for advanced practice nursing were identified as education, starting antibiotic research, utilizing APRN in research and leadership were discussed. Further research is indicated in the effectiveness of outpatient teaching to reduce antibiotic resistance as well as other areas of research the antimicrobial stewardship programs are utilizing in the inpatient settings.
\end{abstract}




\section{Acknowledgements}

I would like to thank all of my loved ones, friends and professors that helped me throughout the process in attaining my masters in nursing. I would especially like to thank my mother and father for being so supportive from the first time I told them I wanted to start a career in the nursing field. 


\section{Table of Contents}

Background/Statement of the Problem .......................................................... 1

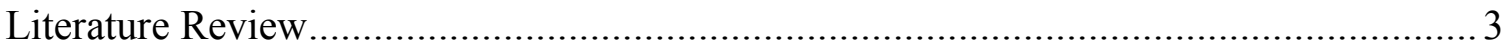

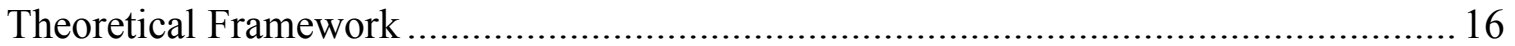

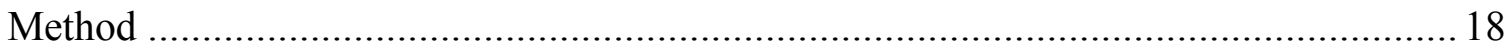

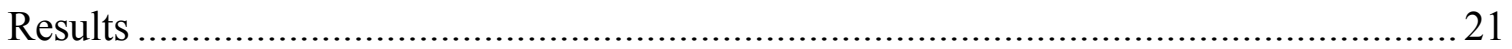

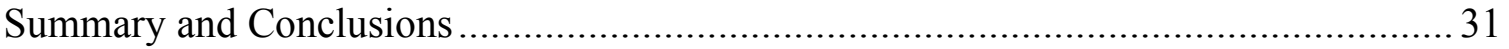

Recommendations and Implications for Advanced Nursing Practice .......................... 34

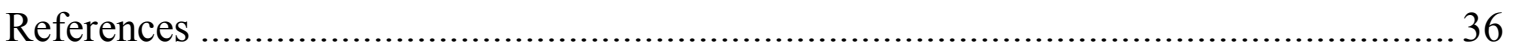

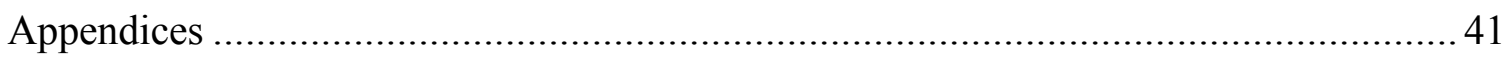




\section{A SYSTEMATIC REVIEW TO EXAMINE THE EFFECTIVENESS OF ANTIBIOTIC}

EDUCATIONAL PROGRAMS IN OUTPATIENT SETTINGS AT REDUCING

ANTIBIOTIC PRESCRIBING?

\section{Background/Statement of the Problem}

According to the Center for Disease Control and Prevention (CDC; 2020), the United States has over 35,000 deaths and over 2 million illnesses per year due to antibiotic resistance. Antibiotic resistance is when bacteria are able to defeat and continue to replicate despite antibiotic treatment. The CDC recommends four ways to reduce antimicrobial resistance (AMR): better lab diagnostics to improve antibiotic prescribing, sharing of data amongst countries, better infection control measures and the appropriate use of antibiotics. The Center of Disease Control (2020) appropriate use of antibiotics includes the overuse and prescribing of antibiotics.

The World Health Organization (WHO; 2018) also identified AMR as a worldwide epidemic. The WHO noted further research into bacterial identification is needed to target specific microbials. Bacterial identification is when a sample is taken and studied to determine the type of bacteria causing infection. Bacterial identification is required to increase the effectiveness of antibiotics. The WHO and CDC acknowledge the need for stricter regulations on antibiotic prescribing. Both organizations believe implementation of antimicrobial stewardship programs (ASP) will help to fight the epidemic of antibiotic resistance in inpatient setting. Antimicrobial stewardship programs consist of teams of infectious disease medical professionals and pharmacists to ensure the proper antibiotic treatments. The ASP also creates educational tools for providers to enhance appropriate antibiotic prescribing practices (WHO, 2018). 
The CDC (2015) found programs dedicated to improving antibiotic use like the ASPs optimize the treatment of infections and reduce adverse events associated with antibiotic use. The CDC (2019) found prevention efforts have reduced deaths from antibiotic-resistant infections by 18 percent overall and by nearly 30 percent in hospital settings. The CDC and WHO describe the amount of antibiotics unnecessarily prescribed is the leading reason for an epidemic of antibiotic resistance. Ventola (2015) demonstrated there is a relationship between antibiotic consumption and the emergence of resistant bacterial strains.

Outpatient settings do not have teams of infectious disease medical professionals and pharmacists to ensure the proper antibiotic treatments like inpatient settings. Most outpatient settings are offices with specific type of providers like primary care, cardiac or infectious disease. The inpatient settings can have infectious disease providers run audits on the prescribed antibiotics for all patients in that setting to focus training on. Education is one of the most important tools for fighting the current antibiotic resistance problem that faces the world today. The question remains would using these antibiotic educational programs be effective in an outpatient setting at reducing antibiotic prescribing? 


\section{Literature Review}

While conducting a review of literature the following databases were searched: MEDLINE, PubMed, and Google Scholar. The search terms used to identify literature included antibiotic development, antibiotic resistance, antibiotic method of action, inpatient and outpatient Antimicrobial Stewardship Program (ASP), antibiotic resistant bacterial infections, outpatient bacterial infections and reduced antibiotic prescribing.

\section{Development of Antibiotics}

Antibiotic development is associated with Paul Ehrlich and Alexander Fleming. Aminov (2010) described how antibiotic use can be traced back to ancient times. Natural traces of tetracycline were found in human skeletal remains and is explained by ancient diets high in tetracycline-containing materials. Paul Ehrlich observed that synthetic dyes could stain certain microbes and not others. From this observation he concluded that chemical compounds could be synthesized that would target specific microbes. In 1904, he began a systematic screening program to find a drug to treat syphilis. Syphilis was usually treated with inorganic mercury salts but Ehrlich and others developed a compound in 1909, Atoxyl, that first cured syphilis in rabbits. Later they developed Salvarsan, which was used in human trials and was a great success. Finally, Neosalvarsan was developed until it was replaced by penicillin in the 1940s. The systematic screening process for bacterial identification became the cornerstone for matching antibiotics drugs to susceptible microbes for the pharmaceutical industry.

Alexander Fleming is credited with discovering penicillin on September 3, 1928. He observed mold that grew on a culture had caused bacteria to die. Others had 
previously made similar observations but Fleming was persistent. He then requested assistance with purification and stability of the active substance and supplied the Penicillium strain to anyone requesting it. An Oxford team led by Howard Florey and Ernest Chain published a paper about purification of penicillin, which eventually led to penicillin mass production and distribution in 1945. Even early on Fleming cautioned about resistance to penicillin if used improperly (Aminov, 2010).

\section{Mechanism of Action of Antibiotics}

Antibiotics are used to treat bacterial infections by causing bacterial cell death. The antibiotic induces cell death by inhibiting essential cellular functions of the bacteria. Antibiotics can be classified by the system they affect and whether they cause cell death (bactericidal drugs) or inhibit the cell growth (bacteriostatic drugs). Most antibiotics either inhibit DNA/RNA synthesis, cell wall synthesis or protein synthesis. Understanding the multilayered mechanisms that kill bacteria is important because of the increased prevalence of AMR bacteria (Kohanski, Dwyer, \& Collins, 2010).

Kohanski et al. (2010) explains bacterial cell death occurs when the formation of double stranded DNA is broken due to the introduction of DNA gyrase inhibitors or the arrest of RNA synthesis with treatment. Bacterial cell wall damage and loss of structural integrity is caused by treatments with cell-wall synthesis inhibitors. Bacterial death from protein synthesis is treated with protein synthesis inhibitors.

\section{Antibiotic Classification}

Antibiotics are classified in several manners. The most common classification is based on their molecular structure or their mode of action. Other classifications include 
route of administration (injectable, oral, and topical). Antibiotics within the same structural class usually show similar effectiveness and toxicity but also share similar side effects. The first group of antibiotics are beta-lactams, they interfere with proteins needed for synthesis of bacterial cell wall and in the process either kills or inhibits their growth. These beta-lactam antibiotics include penicillin, cephalosporins, monobactams and carbapenems (Etebu \& Arikekpar, 2016).

Macrolides, like azithromycin, clarithromycin etc., either kill or inhibit microorganisms by inhibiting protein synthesis. They bind to bacterial ribosome and prevent the addition of amino acid to polypeptide chains during protein synthesis. Quinolones were first discovered as nalidixic acid while in search of antimalarial drugs. These antibiotics interfere with DNA replication and transcription in bacteria. Common quinolones are cinoxacin, norfloxacin, ciproxacin, temafloxacin and others. Aminoglycosides are broad spectrum antibiotics and inhibit protein synthesis by binding to one of the ribosomal subunits. Streptomycin is an aminoglycoside used to treat Mycobacterium tuberculosis (Etebu and Arikekpar, 2016).

Sulfonamides, like trimethoprim and sulfamethoxazole, are generally thought to be bacteriostatic, but they may become bactericidal if the concentration is high enough or if used in the presence of environmental conditions unfavorable to bacteria.

Glycopeptide antibiotics, like vancomycin, act primarily by inhibiting cell wall synthesis of bacteria. Oxazolidinones antibiotics mechanism of action is not yet fully understood; they are reported to interfere with protein synthesis (Etebu and Arikekpar, 2016). 


\section{Complications of Antibiotics}

Antibiotics have common side effects, which cause minor to severe health problems (Anderson, 2019). The side effects are caused by a hypersensitivity to the antibiotic medication. The minor side effects include rash, dizziness, nausea, diarrhea and yeast infections. Minor side effects are usually short term and will usually resolve with completion of the antibiotics or switching the prescribed antibiotic. Yeast infections, oral thrush, and diarrhea can be associated with the loss of normal bacteria and flora due to antibiotic use.

More severe hypersensitivity to antibiotics include allergic reactions, Clostridium difficile infection, and severe stomach cramps. These side effects usually lead to emergency room visits. Anaphylactic reactions are severe hypersensitivity reactions, which include shortness of breath, wheezing, severe nausea/vomiting, lightheadedness, dizziness, rapid heart rate, swelling of the face, lips or tongue, and/or shock (Anderson, 2019).

Other adverse reactions from the use of antibiotics include Stevens Johnson Syndrome (SJS) and Toxic Epidermal Necrolysis (TEN). Stevens Johnson Syndrome and TEN are rare conditions but serious allergic reactions that result in severe skin, mucous membrane disorders, and death. These reactions can occur with all antibiotics but are more commonly associated with sulfonamides, penicillin's, cephalosporins, and fluoroquinolones (Anderson, 2019).

Another adverse condition of antibiotics is antibiotic resistance. The Center for Disease Control (2020) and the World Health Organization (2018) report the rate of 
antibiotic resistance as a world-wide epidemic. The Center for Disease Control (2020) reported 2.8 million antibiotic resistant infections each year with 35,000 deaths. In addition, the CDC reported 223,900 c-diff infections with 12,800 associated deaths each year. The CDC and WHO correlated the antibiotic resistant infections and deaths with over prescribing of antibiotics, improper antibiotic medication administration and slow or inefficient bacterial testing.

\section{Antibiotic Resistance}

Antibiotics are designed to fight and kill bacteria but some of them find new ways to survive. They use resistant mechanisms to defend themselves against antibiotics by using instructions provided by their DNA. Resistance genes are found within plasmids, small pieces of DNA that carry genetic instructions, and are shared to make themselves resistant (CDC, 2020).

There are multiple ways bacteria become resistant. They can restrict access of the antibiotic, get rid of antibiotics, change or destroy antibiotics, bypass the effects of antibiotics or change the targets for antibiotics. An example is certain bacteria can change their outer membrane to keep antibiotic drugs from entering the cell. Pseudomonas aeruginosa bacteria generate pumps to get rid of the antibiotic and klebsiella pneumoniae bacteria can produce enzymes called carbapenemases, which break down carbapenem drugs and most other beta-lactam drugs (CDC, 2020).

The CDC (2019) recommends more specific testing to diagnose bacteria. Specific testing allows the specific bacteria infecting a human to be grown in culture and tested against specific antibiotics. The testing enables the prescriber to know what antibiotic is 
best against that specific bacteria. Another recommendation is longer treatment periods with specific antibiotics to treat bacteria that are resistant to broad spectrum antibiotics.

Research has discovered that a subset of healthy bacteria could prevent colonization against antibiotic resistant bacteria (Pamer, 2016). Antibiotic treatment can damage normal gut bacteria, which could increase susceptibility to infections. Reestablishing normal gut bacteria after antibiotic treatment could help reduce infections. The research is still in the discovery phase but is an example of developing therapies to prevent resistant infections.

Martínez and Baquero (2014) found that there is an emergence of antibiotic resistance and is a relevant problem for human health. Antibiotics cause bacterial growth inhibition by efficiently interacting with its target. There are two ways this occurs: the antibiotic recognizes the bacterial target and there is enough antibiotic to cause inhibition of the bacterial activity. The way antibiotics become resistant is when the bacteria modify their targets or there is a reduction of antibiotics that can access the bacteria (Martinez \& Baquero, 2014).

Ventola (2015) found multiple causes for AMR including overuse, inappropriate prescribing, extensive agricultural use, availability of few, newer antibiotics and regulatory barriers. In 2014, The Intercontinental Medical Statistics (IMS) Health Midas database estimated antibiotic consumption based on the volume of antibiotics sold to be 22.0 standard units (standard units meaning one dose, pill, capsule, or ampoule) of antibiotics prescribed per person in the U.S. It found $30 \%$ to $50 \%$ of all antibiotics prescribed were incorrect due to the wrong treatment indication, choice of antibiotic or 
duration of use (Van Boeckel et al., 2014). The antibiotics sold to farmers of livestock in the U.S. accounts for $80 \%$ of all antibiotics sold. These animals lose healthy bacteria in the gut leading to overgrowth of resistant bad bacteria and is transferred to humans with consumption. Finally, the regulatory barriers to develop new antibiotics and low cost of selling them make it difficult and not profitable for drug companies to even attempt creating such products.

\section{Resistant Antimicrobials}

AMR is now considered one of the greatest threats to human health worldwide. The CDC (2018) reported Methicillin-resistant Staphylococcus aureus (MRSA) kills more Americans every year than emphysema, HIV/AIDS, Parkinson's disease and homicide combined. The CDC posted a weekly report that stated MRSA is a major cause of infection, from superficial to invasive infection, sepsis and death (Kourtis et al., 2019). It does point out that progress has been made in preventing infection but evidence suggests that the declining rate has slowed. In 2017, an estimated 119,247 S. aureus bloodstream infections with 19,832 associated deaths.

Tuberculosis (TB) is now linked to AMR strains and antibiotics that have been effective against TB are now insufficient. The American Lung Association (2020), explains that TB can occur after inhaling Mycobacterium tuberculosis (M. tuberculosis) bacteria from a person with active TB and the bacteria can destroy the lung tissue. The WHO (2019) states that only half of multidrug resistant TB is treated effectively. Other infections are resistant to previously effective antibiotics because the antibiotics are used frequently or inappropriately. There is a lack of research and development into new 
antibiotic development because preexisting antibiotics have already been developed to cure infections and new antibiotics are considered unnecessary (WHO, 2019).

The WHO (2019) stated antibiotics resistance is not a problem just in underdeveloped countries but worldwide. Common community acquired bacterial infections including TB, gonorrhea, typhoid fever and Group B streptococcus have been noted as becoming AMR. Community-acquired AMR is more concerning because of the ease of transmission. These infections are usually transferred to patients that are already susceptible to other infections.

\section{Strategies to Fight Antibiotic Resistance}

Since the emergence of the AMR epidemic in 2013, the CDC released the first report, Antimicrobial Resistance Threats Report, about harm to human health posed by antibiotic resistance, which prompted government and industry leaders to take action. The report described the danger of antibiotic resistance and stated that each year in the U.S. at least 2 million people get an antibiotic-resistant infection and at least 35,000 people die from AMR. In 2014, the President's Council of Advisors on Science and Technology (PCAST) released a report to combat AMR. The report included sections for federal investment and leadership, monitoring antibiotic resistance, new antibiotics, stewardship of current antibiotics for humans/animal agriculture and international cooperation. The report showed that current antibiotic stewardship programs are not sufficient throughout the United States and in only 50 percent of hospitals. It further discussed the need to expand the steward programs into outpatient settings (CDC, 2013). 
The president issued Executive Order 13676, which directed federal agencies to implement the recommendations in the PCAST. In 2015, the White House hosted the Forum on Antibiotic Stewardship and released a five-year national action plan, outlining steps for implementing the national strategy to combat antibiotic resistance. The same year congress appropriated funds to support the National Action Plan. In 2016, the U.S. government participated in the United Nations (UN) General Assembly High-Level Meeting on Antimicrobial Resistance, where nations passed a resolution to combat antibiotic resistance worldwide. In 2017, the U.S. President issued an executive order to continue advisory committees that showed commitment to combating antibiotic resistance. Finally, in 2018, the U.S. government participated in the UN General Assembly High-Level Meeting, which covered antibiotic resistance and launched the Antimicrobial Resistance Challenge (ARC). ARC is a year-long campaign by CDC that encourages global organizations to commit further progress against resistance (CDC, 2019).

The WHO (2019) states that there needs to be coordinated action to fight against antimicrobial resistance. AMR is a complex problem that affects all of society. All countries need national action plans and greater innovations and investments to research and the development of antibiotics, vaccines and diagnostic tools. The WHO recommends a Global Antibiotic Research and Development Partnership (GARDP), which is a joint initiative that encourages research and development through publicprivate partnerships. They hope to develop new antibiotic treatments by 2023 . They also propose the "Interagency Coordination Group on Antimicrobial Resistance" (IACG), which will coordinate between nations a sharing of antimicrobial knowledge. The final 
recommendation is for the implementation of antimicrobial stewardship programs (ASP) to help combat the already existent problems with overprescribing and incorrectly prescribed antibiotics.

\section{Antimicrobial Stewardship Program}

The CDC and WHO both recognize the importance of antibiotic resistance in overall health. Both of these organizations have multiple strategies to help combat the antibiotic resistance world-wide epidemic and it primarily starts with the use of antimicrobial stewardship programs. Stewardship programs have multiple strategies in fighting against the persistent antibiotic resistant crisis that is currently happening (CDC, 2019).

The CDC (2019) identifies core elements to an antibiotic stewardship program. The elements start with leadership commitment to dedicating staff, technology and resources. An appointed leader who is responsible for the program outcomes is key. Drug expertise is needed hence an appointed pharmacist leader is a valuable member to improve antibiotic use.

An article by MacDougall (2005), explains that ASPs in inpatient settings vary and can include antibiotic policies, antibiotic management programs, antibiotic control programs, and other terms. In general, they discuss what type of oversight is used at a healthcare institution to help with antibiotic resistance rates. The programs may allow for substitution of antimicrobials in the same class for cost-saving purposes, switch intravenous-to-oral for highly bioavailable drugs, and pharmacokinetic consultation 
services that impact antimicrobial use. The CDC (2019) showed that since 2013, these ASPs have reduced the total AMR $18 \%$ overall and $30 \%$ in hospital settings.

The ASPs may include infectious diseases physicians, pharmacists, microbiologists, infection control staff, hospital epidemiologists and hospital administrators. The team can implement and design how the AMS program functions. The team ensures therapeutic guidelines, antimicrobial restriction policies, or other measures are based on the best evidence available with low risk to patients. ASPs use education techniques to try and reduce the amounts of antibiotics prescribed. Lee et al. (2015) conducted a systematic review that concluded it is important to develop effective educational programs to reduce antibiotic use. The findings support the importance of not only educating prescribers but also to include other medical professionals and the public.

\section{Outpatient Antibiotics and Education}

According to The Pews Report (2016), approximately 13\% (154 million visits annually) of all outpatient office visits in the United States result in an antibiotic prescription and 30\% (47 million prescriptions) are unnecessary. Outpatient antibiotics prescribed for patients with acute respiratory conditions (sinus infections, middle ear infections, pharyngitis, viral upper respiratory infections, bronchitis, asthma, allergies, influenza, and pneumonia) accounts for $44 \%$ of all prescriptions. Half of these prescriptions are unnecessary because they are viral or other conditions that do not require antibiotics. 
Feller (2019) published a commentary on the Rhode Island Medical Society webpage titled "Why do doctors overprescribe antibiotic?" which explains multiple reasons for overprescribing. It shows that antibiotics are ordered for disorders not caused by bacteria, bacterial culture results that were contaminated, broad-spectrum antibiotics over narrow spectrum, duration longer than required, wrong doses and antibiotics before culture results or without diagnostic testing. Then it further explains that these decisions to prescribe are made because of cognitive influences. For physicians they might believe antibiotics are "risk free", undervalue long term risks, have a fear of malpractice, lack of physicians' diagnostic skills and writing a prescription rather than explaining why it is not needed. Patients may be influenced by media which may mislead them into a need for antibiotics and fear of "infections". Patients and physicians more easily recall someone "cured" with antibiotics and do not understand the antibiotic resistance. Finally there is a patient-centered care movement which means patients are more likely to request or demand medications.

. The CDC (2019) has posted guidelines, "The Core Elements of Outpatient Antimicrobial Stewardship" which reviews the fundamental elements of the program. The four core elements of outpatient antibiotic stewardship listed are commitment, action for policy and practice, tracking and reporting, and education and expertise. The guidelines explain each of the elements and encourages outpatient settings to commit to at least one policy to improve antibiotic prescribing. This offers outpatient settings with educational resources to patients and families on appropriate antibiotic use and clinicians with education aimed at improving antibiotic prescribing. This also provides clinicians with access to experts in established antibiotic stewardship. The program is not 
mandatory for outpatient providers, however the individual providers have to accept these programs before it can be implemented. It is a call to action for outpatient centers to join in the fight against antibiotic resistance. Will antibiotic educational programs be effective in an outpatient setting at reducing antibiotic prescribing? 


\section{Theoretical Framework}

The theoretical framework used for this systematic review was the Preferred Reporting Items for Systematic Reviews and Meta-Analyses (PRISMA). The PRISMA Statement was created to improve the reporting of systematic reviews and meta-analyses. PRISMA can also be used for reporting systematic reviews of other types of research, particularly evaluations of interventions. PRISMA is useful for critical appraisal of published systematic reviews (Moher, Liberati, Tetzlaff, Altman, The PRISMA Group, 2009).

PRISMA statement consists of a 27-item checklist (Appendix A) and four-phase flow diagram (Appendix B). The checklist is divided into seven sections including title, abstract, introduction, methods, results, discussion, and funding. Each of these sections have criteria listed to complete each section. It summarizes all of the results from multiple studies into a single document.

A four-phase flow diagram (Appendix B) shows the flow of information through the different phases of searching for randomized control trials and maps out the number of records identified, included and excluded, and the reasons for exclusions (Moher et al., 2009). Identification finds research studies within online databases and uses search terms in different combinations. This allowed the following terms to be utilized: Antimicrobial Stewardships Programs, prescribing, education, bacteria, antibiotics, reduce antibiotic, outpatient, primary care and randomized control trial. The results were checked to eliminate duplicate studies and appropriateness for research articles that applied to the research question. Then eligibility of the studies left were checked to see if they met 
specific inclusion and exclusion criteria. Inclusion criteria were outpatient settings, antibiotic teaching, and studies within the last 10 years. Exclusion criteria consisted of inpatient settings and only new educational programs for antibiotic prescribing. Finally, there were five randomized control trials found for the systematic review. 


\section{Method}

\section{Purpose/Clinical Question/Outcomes Examined}

The purpose of this systematic review was to determine if educational programs help to combat the world-wide epidemic of AMR in an outpatient setting. The clinical question is to examine the effectiveness of antibiotic educational programs in outpatient settings at reducing antibiotic prescribing? The articles were reviewed to see if educational programs helped to lower the amount of antibiotics used in outpatient settings without causing harm to patients.

\section{Inclusion/Exclusion Criteria/Limits}

The systematic review included studies involving patients in outpatient settings that require antibiotics. Inclusion criteria included randomized control trials that reviewed the rates of antibiotic prescribing in outpatient settings while using an educational program for recommended antibiotic prescribing and teaching for healthcare staff and patients. Exclusion criteria included any randomized control trials that are older than ten years, patients that are hospitalized or in long term care facilities.

\section{Procedure}

A literature search was conducted utilizing the search engines MEDLINE, PubMed, Google Scholar and CINHAL. The search criteria included Antimicrobial Stewardships Programs, prescribing, education, bacteria, antibiotics, reduce antibiotic, outpatient, primary care and randomized control trial. A total of five articles were identified for the systematic review. 
Using the PRISMA four-phase diagram (Appendix A), 337 studies were identified and after being screened for duplicates, 117 articles were left. The 117 articles were screened for eligibility and 80 were excluded. The majority of articles were excluded for they were not specific to the outpatient setting. The remaining 37 full text studies were further assessed for eligibility, which resulted in 5 appropriate randomized control trials. The PRISMA four-phase diagram helped determine these articles were appropriate for this systematic review (Moher et al., 2009).

Data collection. The data was organized in a collection table (Appendix C). The data collected included the title of study, author(s), and type of randomized control trial. The aim/purpose and design for the study was listed as well as the sample of patients and providers. Finally the method of education was listed and the outcomes after receiving antibiotic education.

Table 1. (Appendix C) Study:

\begin{tabular}{|l|l|l|l|l|}
\hline$\underline{\text { AIM/PURPOSE }}$ & $\underline{\text { DESIGN }}$ & $\underline{\text { SAMPLE }}$ & $\underline{\text { METHODS }}$ & OUTCOMES \\
& & & & \\
\hline
\end{tabular}

Critical appraisal. The data was appraised using the Critical Appraisal Skills Program (CASP) checklist. The CASP has 11 questions to evaluate the randomized control trials and determine the quality of the randomized control trials included in the 
systematic review. The check list of questions determined the validity and conception of results and if they can be applied to the population chosen (Casp UK, 2013). A checklist was done for each of the five articles chosen (Appendix D).

Cross-study analysis. A cross-study analysis compared the different randomized control trials included in the systematic review. Using the cross-study analysis helped to summarize if educational programs reduced the amount of prescribed antibiotics in an outpatient setting. Each study was listed with the type of educational intervention used and the outcomes of antibiotic prescribing after the intervention (Appendix E).

Table 2. (Appendix E)

\begin{tabular}{|c|c|c|}
\hline Study & Intervention & Outcomes \\
\hline & & \\
& & \\
\hline
\end{tabular}




\section{Results}

The Prisma four-phase flow diagram (Appendix A) guided the process of identifying five randomized control trials. The PRISMA 27 item checklist (Appendix B) was used to identify the randomized control trials used for this systematic review. A data table (Appendix C) organized the findings of each randomized control trials based on the purpose, design, sample, methods and outcomes. The randomized control trials were assessed from the Critical Appraisal Skills Programme (CASP), a randomized control trial checklist (Appendix D). Lastly, the studies were summarized in a cross study analysis to compare the outcomes across the studies (Appendix E).

\section{Individual Study Results}

The randomized control trial completed by Butler et al. (2012) evaluated the effectiveness and cost of a multifaceted flexible educational program that was aimed at reducing antibiotic dispensing in primary care. The article describes the online training program STAR: Stemming the Tide of Antibiotic Resistance. This program includes case studies, provider reflection on prescribing antibiotics, choice of antibiotics, nonmedical factors that influence prescribing decision and patient communication. It reinforces healthcare providers concepts of AMR and reflects when to prescribe antibiotics.

The sample from Butler et al. (2012) was comprised of 68 general practices with an estimated 480,000 patients in Wales, United Kingdom. Thirty-four practices were randomized to receive the education program and 34 practices to be the control with no education program. Dynamic block allocation was used to achieve balance between 
groups of practices for rate of antibiotic dispensing, practice size, and proportion of clinicians. Practices were then divided into three arms with 24, 22 and 22 practices in each arm. Each arm was then divided into an intervention group or control group. The outcomes measured the number of antibiotics prescribed for all causes per 1000 patients in a year compared to previous year in the intervention group. They also compared the rate of prescribed antibiotics for all causes per 1000 patients in a year compared to the previous year in the control group. Finally both the intervention group and the control group were compared to each other.

The results from Butler et al. (2012) showed the rate of antibiotic prescriptions per 1000 patients decreased by 14.1 per 1000 patients in the intervention group and an increase of 12.1 per 1000 patients in the control group showing a net difference of 26.2 per 1000 patients. After adjustments for baseline dispensing a 4.2 percent reduction in oral antibiotic dispensing was found for the year relative to the control group $(\mathrm{P}=0.02)$. The reduction of antibiotic prescribing was found in all classes of antibiotics except for with penicillinase-resistant penicillin. The largest prescription reduction was associated with phenoxymethylpenicillins (penicillin V) and macrolides. There was no evidence that the intervention prevented hospital admissions or inpatient revisits for respiratory tract infections.

The Butler et al. (2012) study showed that the learning approach used for education for clinicians was effective in reducing the amount of antibiotic prescribing. Using the Critical Appraisal Skills Program (CASP) randomized controlled trials checklist, it showed the results of the trial as valid except the participants were not blind to the study. The results apply to the context of this systematic review and the outcomes 
were considered. The benefits were worth the costs as it showed no harm to any of the participants.

The cluster randomized trial by Gerber et al. (2013) evaluated the effect of outpatient antimicrobial stewardship interventions on antibiotic prescribing for pediatric outpatients. The trial was set up by block-randomized practices (clusters) by location and volume. The unit of observation was the provider but randomized at practice level to avoid intra-practice contamination of the intervention. A network of 25 pediatric primary care practices in Pennsylvania and New Jersey were chosen and 18 practices participated including 162 clinicians.

The intervention from Gerber et al. (2013) was a one-hour on-site clinician education session followed by personalized, quarterly/audit feedback on prescribing for bacterial and viral acute respiratory tract infections (ARTIs). Broad spectrum antibiotic prescribing for bacterial and viral ARTIs were compared for one year after the intervention in the intervention group and control.

The Gerber et al. (2013) study obtained electronic health records used by all practice sites for charting and prescribing from office and telephone encounters. The results showed that broad spectrum antibiotic prescribing decreased from $26.8 \%$ to $14.3 \%$ in the intervention practices and only $28.4 \%$ to $22.6 \%$ in the control practices (difference of difference [DOD], 6.7 percent; $\mathrm{P}=0.01)$. The study measured off guideline prescribing for children: off guideline prescribing for pneumonia decreased from $15.7 \%$ to $4.2 \%$ in the intervention group compared to $17.1 \%$ to $16.3 \%$ in the control group (DOD, 10.7 percent; $\mathrm{P}<.001$ ), and prescribing related to acute sinusitis decreased from 
$38.9 \%$ to $18.8 \%$ in the intervention group compared to $40.0 \%$ to $33.9 \%$ in control group (DOD, 14.0 percent; $\mathrm{P}=.12$ ) respectively. The off guideline prescribing for streptococcal pharyngitis and viral infections was determined to be at baseline.

The results from Gerber et al. (2013) showed that clinician education and feedback improved adherence to prescribing guidelines for bacterial ARTIs. There was no difference noted with prescribing for viral infections. The results of this trial using CASP showed that these results were valid. The difference between groups was significant considering the changes in trajectories of broad-spectrum prescribing before and during the intervention between the two groups of practices. The results show that the antimicrobial stewardship education helped locally to lower the rate of unnecessary antibiotic prescribing and concluded the results can be generalized. The article did not discuss if all of the participants were truly blind to the study.

The three-arm, cluster-randomized trial by Gonzales et al. (2013) compared the impact of two decision support strategies for antibiotic treatment of acute bronchitis. There were 33 primary care practices in central Pennsylvania chosen for the trial. These practices consisted of 9 large practices (with 9,000 to 15,000 annual patient visits) that were randomly assigned to each study arm. The remaining 23 smaller practices (with 2,000 to 9,000 annual visits) were also randomly assigned to each study arm. Eleven practices received printed decision support (PDS) for acute cough illness, 11 other practices received electronic medical record-based decision support (CDS) and 11 practices comprised the control group. 
Gonzales et al. (2013) provided the PDS printed information for patients when they had a chief complaint of "cough". An informational poster on common causes of cough and treatments was placed in the exam room. The CDS sites were alerted to "best practice alert" when chief complaint of cough was entered into the electronic health record. The CDS sites had an electronic alert and "Smart Set" utilization when captured at the patient record level while inputting symptoms. The "Smart Set" would create order sets for relevant testing and treatment options for bronchitis, pneumonia, sinusitis, URI and influenza. Then a template was provided to include documenting relevant history and physical exam findings for patients with acute respiratory infections (ARI). This data helped to categorize the probability of pneumonia and groups of electronic order sets were created to simplify testing and treatment options for bronchitis, pneumonia, sinusitis, ARI, and influenza. Both groups received clinician education and feedback on prescribing practices and patient education brochures. Antibiotic prescription rates for uncomplicated acute bronchitis for the winter of 2009-2010 were compared with the previous 3 winter periods.

Gonzales et al. (2013) showed the PDS group antibiotic prescribing decreased from $80.0 \%$ to $68.3 \%$. The CDS group antibiotic prescribing decreased from $74 \%$ to $60.7 \%$. The control group increased slightly from $72.5 \%$ to $74.3 \%$. The differences for the intervention groups were significant from the control (control vs. PDS P $=0.003$; control vs. CDS $\mathrm{P}=0.014)$. The change was not significant between the two intervention groups (PDS vs. CDS P = 0.67). However, one-third of all providers reduced their antibiotic prescribing by over $20 \%$ in both intervention groups. 
The CASP showed that results of the Gonzales et al. (2013) trial were valid. It wasn't clear if the groups were blind to the study as all of the primary care practices belonged to an integrated health care system and from the same area. The outcomes of implementing strategies for clinical algorithm-based decision support for acute cough were equally effective with printed and computer-assisted approaches. These results can be applied to this research and all outcomes were considered. The study showed no significant differences in the return rate of patient visits after the intervention, suggesting the decrease in antibiotic treatments were not associated with adverse effects.

The randomized control trial by McNulty et al. (2018) studied whether local trainer-led TARGET antibiotic workshops would improve the rate of antibiotic prescribing in general practices. The trial used the McNulty-Zelen cluster randomized control trial design, which conceals from educational participants that they are in a trial. The trial obtains consent from a trusted third party to give consent on participants' behalf, then intervention practice staff choose whether to attend the offered education. The study used the McNulty-Zelen-design randomized controlled trial within three regions of England, 152 general practices were stratified by clinical commissioning group, antibiotic dispensing rate and practice patient list size. The practices were randomly allocated and 73 practices were offered the TARGET intervention.

TARGET workshops in the McNulty et al. (2018) trial included a presentation, antibiotic reflective data, providing staff and patient resources, clinical scenarios and action planning. The program included TARGET leaflets that are patient-focused and include information about self-care, expected illness duration and when to reconsult a 
physician. These patient-focused teaching pamphlets explain the need for antibiotics and help the provider with delayed prescribing of antibiotics to their patients.

The McNulty et al. (2018) study had 36 practices (51\%) that accepted TARGET workshop invitation and 79 control practices. There was an intent-to-treat (ITT) analysis done that showed a $2.7 \%$ lower rate of total antibiotic prescribing in the intervention practices compared to the control group $(\mathrm{P}=0.06)$. These rates include $4.4 \%$ lower prescribing of amoxicillin/ampicillin $(\mathrm{P}=0.02)$ and 5.6\% lower for trimethoprim $(\mathrm{P}=$ 0.03 ) and a non-significant $7.1 \%$ higher rate for nitrofurantoin compared to the control $\operatorname{group}(\mathrm{P}=0.06)$.

The CASP shows that the results of the McNulty et al. study were valid. After the McNulty et al. (2018) trial, the Complier Average Casual Effect (CACE) analysis showed that there was a $6.1 \%$ lower antibiotic prescribing rate and $11 \%$ trimethoprim prescribing in the intervention with TARGET practices compared to the control. The use of TARGET workshops including the freely available resources reduced the rate of antibiotic prescribing in primary care. The trial shows education benefits this research with no evidence of harm to the patients.

The Legare et al. (2010) trial showed that involvement of patients leads to shared decision making (SDM) during the visit. This would also provide optimal decisions by the FPs and patient that would translate into optimal prescribing. The two-arm parallel clustered pilot randomized control trial was used to develop, adapt, and validate DECISION+ and estimate its impact on antibiotic use by family physicians (FPs) and their patients for acute respiratory infections (ARI). DECISION+ protocol educates FPs 
about probability of bacterial versus viral ARI with benefits and risks associated with each option. It provided strategies to communicate with the patient and how to involve patients in the decision making of antibiotics use. A biostatistician simultaneously randomized four family medicine groups (FMGs) to the immediate DECISION+ experimental group and the delayed DECISION+ control group. From the 4 FMGs, there were $33 \mathrm{FPs}$ and 459 patients that participated $(\mathrm{FMGs}=2, \mathrm{FPs}=18$, patients $=245)$ and the control group $(\mathrm{FMGs}=2, \mathrm{FPs}=15$, patients $=214)$. The experimental group had received peer training sessions and workshops that the control group did not when initiating the DECISION+ program.

The CASP shows valid results for this trial and for experimental group, $21 \%$ fewer patients decided to use antibiotics immediately compared to the $8 \%$ in the control group $(\mathrm{P}=0.08)$. Out of the $33 \mathrm{FPs}$, three $(9 \%)$ dropped out of the Legare et al. (2010) trial with no reasons explained. The experimental group had 20 patients (8\%) drop out of the trial and 14 patients (5\%) from the control group because they did not follow up in two weeks. It was also unclear if the study was a true blind study as the FPs in the control group could have looked up DECISION+ information. The study found education for providers and patients contribute to the reduction of antibiotic prescribing. The DECISION+ program lowers the antibiotics for ARIs without adverse patient outcomes.

\section{Cross-Study Analysis}

All five of the randomized control trials found that educational programs reduced the overall prescribing of antibiotics. Butler et al. (2012) used the Stemming the 
Tide of Antibiotic Resistance (STAR) educational program and showed a rate of oral antibiotic dispensing decreased by 14.1 per 1000 in the intervention group and increased by 12.1 per 1000 in the control group for a net difference of 26.1 per 1000 . The Gerber et al. (2013) used clinician education coupled with audit and feedback of an antibiotic prescribing to children with ARTIs. This showed a broad-spectrum antibiotic prescribing decreased from $26.8 \%$ to $14.3 \%$ among intervention practices and only $28.4 \%$ to $22.6 \%$ in the control. Off-guideline prescribing for children with pneumonia decreased from $15.7 \%$ to $4.2 \%$ among intervention practices and $39.8 \%$ to $18.8 \%$ for acute.

Gonzales et al. (2013) used two intervention groups with printed decision support (PDS), a computer decision support (CDS) and a control group. PDS group antibiotic prescribing decreased from $80.0 \%$ to $68.3 \%$, CDS group decreased from $74 \%$ to $60.7 \%$ and the control group increased slightly from $72.5 \%$ to $74.3 \%$ for prescribed antibiotics for acute cough illnesses. It was also found that one third of the providers in intervention groups reduced prescribing antibiotics all together by 20\%. The McNulty et al. (2018) study had intervention participants that complete a TARGET workshop. This study showed a $6.1 \%$ lower antibiotic prescribing rate and $11 \%$ lower trimethoprim prescribing in the intervention with TARGET practices compared to the control. Finally Légare et al. (2010) used DECISION+ and showed 21\% fewer patients decided to use antibiotics immediately and the control group only $8 \%$ fewer patients decided to use antibiotics. Percentage of patients who decided to use antibiotics after consultation was $52.2 \%$ in the control group and $27.2 \%$ in the experimental group.

Not all clinicians in each practice had participated so studies that would analyze data from practices where all clinicians participated could increase potential practice 
effects on antibiotics. The studies also do not include patients' perceptions of antibiotics, which sometimes drives the prescribing of antibiotics for patient satisfaction. 


\section{Summary and Conclusions}

The CDC and WHO have determined that AMR is a growing epidemic that needs further investigation and research to lower the rates of resistance. According to the Center for Disease Control and Prevention (CDC, 2020), the United States has over 35,000 deaths and over 2 million illnesses per year due to antibiotic resistance (WHO, 2020). The WHO and CDC acknowledge the need for stricter regulations on antibiotic prescribing.

Both organizations found implementation of ASPs helps fight the epidemic of antibiotic resistance in inpatient setting. One key aspect of ASPs effort to reduce AMR is the creation of educational tools for providers to enhance appropriate antibiotic prescribing practices (WHO, 2018). The purpose of this systematic review is to examine the effectiveness of antibiotic educational programs in an outpatient setting.

To research this a search of current randomized control trials from the past ten years was done using MEDLINE, PubMed, Google Scholar and CINHAL. The search criteria included antimicrobial stewardship programs, outpatient, bacteria, antibiotics, primary care and randomized control trial. Using the Prisma 4-phase flow diagram (Appendix A) (Moher, 2009), 5 randomized control trials were selected with the assistance of the PRISMA 27 item checklist (Appendix B).

The data from each of the randomized control trials was organized into a data table (Appendix C). The purpose, design, sample, methods and outcomes of the studies where listed. The Critical Appraisal Skill Program (CASP) was used to critically appraise the different types of evidence in each study. Finally, a cross study analysis data table (Appendix E) was utilized with each studies name, interventions and outcomes. The 
studies were categorized with the name of the study, the interventions used and the outcomes of the study.

All of the studies included show that when antibiotic education is provided in an outpatient setting, providers reduce their rates of antibiotic prescribing. These studies show that with education and training in an outpatient setting, lower prescribed antibiotics can be achieved. They also focused on outpatient prescribing and teaching to reduce the amount of prescribed antibiotics for unnecessary illness.

The CDC points out four ways to reduce AMR and these studies focused on the appropriate use of antibiotics (CDC, 2019). There is still a need for better lab diagnostics to improve antibiotic prescribing, sharing of data and better infection control measures. Studies could compare data about diagnostic machines to see which ones were more accurately testing specimens. The outpatient settings could determine if sharing of data amongst each other would help to lower antibiotic prescribing rates. Studies could also compare rates of bacterial infections to seasons or by age group to see if each practice is prescribing at the same rates as others.

The World Health Organization (WHO, 2018) also acknowledges the need for stricter regulations on antibiotic prescribing. The ASPs have already been established in the inpatient setting and they have in-house pharmacist, infectious disease consults, and computer algorithms that help antibiotic prescribing. Currently outpatient settings are not all electronically linked so it makes it more difficult to use the ASPs found in electronic algorithms. Studies could be performed at the pharmacy level to see if they could track providers and amounts of antibiotic being prescribed by individual providers. The 
pharmacists could also require confirmed laboratory data before filling antibiotic prescriptions.

The educational tools being developed and studied appear to lower the amounts of antibiotics prescribed. This systematic review shows that outpatient antibiotic educational programs are effective. These educational programs effectively help continue to lower the amount of antibiotic resistance the world faces today but further research is needed. 


\section{Recommendations and Implications for Advanced Nursing Practice}

The CDC and WHO have clearly provided data that antibiotic resistance is a worldwide issue that needs to be addressed. The evidence is supported by both organizations and multiple recommendations to help with resistance are suggested including utilizing educational programs for providers and patients. Educational programs have developed training tools, teaching seminars, chart reviews, evidencebased practice prescribing recommendations, patient teaching, and joint patient/provider decision making.

The five studies included in this systematic review all showed that implementing the education programs helped to lower the amount of prescribed antibiotics without adverse effects to the patient. These studies prove to the advanced practice registered nurse (APRN) that education plays a key role in decision making about prescribing. Some of the studies included the patients in decision making which helped providers to not prescribe antibiotics, without patient satisfaction being compromised.

The role of an APRN includes research and education to help all APRNs in following evidence-based practice in the field. An article by Harbman et al. (2016) states that health care administrators are seeking new ways to utilize all dimensions of APRN expertise, especially related to research and evidence based practice. The article showed that international studies reveal research as the most underdeveloped and underutilized aspect of these roles. The APRNs should be utilized in conducting point of care research, quality improvement and evidence based practice projects. This helps healthcare systems to improve patient, provider, and system outcomes which benefits everyone. 
An article by Lamb et al. (2018) was aimed at describing the leadership capabilities of advanced practice nurses. It showed that the APRN should be considered in organization's patient focused leadership and organization/system focused leadership. The article describes APRNs as leaders that can contribute to environmental improvements for patients, families, nurses, healthcare providers and the healthcare system. With education and evidence-based practice/research being conducted by APRNs, they can help implement strategies to reduce the overprescribing of antibiotics.

The role of an APRN is not just limited to being a provider for patients. All APRNs should consider themselves as providers that can research best practice and implement change in the healthcare systems that they work in. If there is a lack of education or research, the APRN should recognize the need and try to implement it. Using current research and starting programs, like the educational programs discussed, is within the role of the APRN. 


\section{References}

American Lung Association. (2020, May 1). Tuberculosis

(TB).https://www.lung.org/lung-health-diseases/lung-disease-lookup/tuberculosis

Aminov, R. I. (2010). A brief history of the antibiotic era: Lessons learned and challenges for the future. Frontiers in Microbiology. doi:10.3389/fmicb.2010.00134

Anderson, L. (2019). Antibiotics - Common side effects, allergies and reactions. Retrieved from https://www.drugs.com/article/antibiotic-sideeffects-allergiesreactions.html

Butler, C. C., Simpson, S. A., Dunstan, F., Rollnick, S., Cohen, D., Gillespie, D., ... Hood, K. (2012). Effectiveness of multifaceted educational programme to reduce antibiotic dispensing in primary care: practice based randomised controlled trial. The British Medical Journal, 344(feb021), d8173-d8173. doi: 10.1136/bmj.d8173

CASP checklists - CASP - Critical Appraisal Skills Programme. (2019, November 1). Retrieved from $\underline{\text { https://casp-uk.net/casp-tools-checklists/ }}$

Centers for Disease Control and Prevention. (2020, March 13). Biggest threats and data. https://www.cdc.gov/drugresistance/biggest-threats.html

Centers for Disease Control and Prevention. (2019, November 14). Core elements of outpatient antibiotic stewardship. https://www.cdc.gov/antibiotic-use/coreelements/outpatient.html 
Centers for Disease Control and Prevention (2019, December 1). U.S. national strategy for combating antibiotic-resistant bacteria (National Strategy). https://www.cdc.gov/drugresistance/us-activities/national strategy.html

Etebu, E., \& Arikekpar, I. (2016). Antibiotics: Classification and mechanisms of action with emphasis on molecular perspectives. International Journal of Applied Microbiology and Biotechnology Research, 4, 90-101. Retrieved from https://pdfs.semanticscholar.org/aebc/840138529c147e54552205bf26ec8aa3ca2e. pdf

Feller, E. (2019, February). Why do doctors overprescribe antibiotics? Retrieved August 29, 2020, from http://www.rimed.org/rimedicaljournal/2019/02/2019-02-09feller.pdf

Gerber, J. S., Prasad, P. A., Fiks, A. G., Localio, A. R., Grundmeier, R. W., Bell, L. M.,...Zaoutis, T. E. (2013). Effect of an outpatient antimicrobial stewardship intervention on broad-spectrum antibiotic prescribing by primary care pediatricians. Journal of the American Medical Association, 309(22), 2345-2352. doi:10.1001/jama.2013.6287

Gonzales, R., Anderer, T., Mcculloch, C. E., Maselli, J. H., Bloom, F. J., Graf, T. R., ... Metlay, J. P. (2013). A cluster randomized trial of Decision support strategies for reducing antibiotic use in acute bronchitis. Journal of the American Medical Association Internal Medicine, 173(4), 267-263. doi:

10.1001/jamainternmed.2013.1589 
Harbman P. (2014). The development and testing of a nurse practitioner secondary prevention intervention for patients after acute myocardial infarction: a prospective cohort study. International Journal of Nursing Studies, 51(12), 1542-1556. https://doi.org/10.1016/j.ijnurstu.2014.04.004

Kohanski, M. A., Dwyer, D. J., \& Collins, J. J. (2010). How antibiotics kill bacteria: From targets to networks. Nature Reviews Microbiology, 8(6), 423-435. doi:10.1038/nrmicro2333

Kourtis A.P., Hatfield K., Baggs J, et al. Vital signs: Epidemiology and recent trends in methicillin-resistant and in methicillin-susceptible Staphylococcus aureus bloodstream infections - United States. Morbidity and Mortality Weekly Report 2019;68:214-219. DOI: http://dx.doi.org/10.15585/mmwr.mm6809e1

Lamb, A., Martin-Misener, R., Bryant-Lukosius, D., \& Latimer, M. (2018). Describing the leadership capabilities of advanced practice nurses using a qualitative descriptive study. Nursing Open, 5(3), 400-413. doi: 10.1002/nop2.150

Lee, C.-R., Lee, J. H., Kang, L.-W., Jeong, B. C., \& Lee, S. H. (2015). Educational effectiveness, target, and content for prudent antibiotic use. BioMed Research International, 2015, 1-13. doi: 10.1155/2015/214021

Légaré F, Labrecque M, LeBlanc A, et al. Training family physicians in shared decision making for the use of antibiotics for acute respiratory infections: a pilot clustered randomized controlled trial. Health Expect. 2011;14 Suppl 1(Suppl 1):96-110. doi:10.1111/j.1369-7625.2010.00616.x 
MacDougall, C., \& Polk, R. E. (2005). Antimicrobial stewardship programs in health care systems. Clinical Microbiology Reviews, 18(4), 638-656. https://doi.org/10.1128/CMR.18.4.638-656.2005

Martínez, J. L., \& Baquero, F. (2014). Emergence and spread of antibiotic resistance: Setting a parameter space. Upsala Journal of Medical Sciences, 119(2), 68-77. doi:10.3109/03009734.2014.901444

McNulty, C., Hawking, M., Lecky, D., Jones, L., Owens, R., Charlett, A., ... Francis, N. (2018). Effects of primary care antimicrobial stewardship outreach on antibiotic use by general practice staff: pragmatic randomized controlled trial of the TARGET antibiotics workshop. Journal of Antimicrobial Chemotherapy, 73(5), 1423-1432. doi: 10.1093/jac/dky004

Moher D, Liberati A, Tetzlaff J, Altman DG, The PRISMA Group (2009) Preferred Reporting Items for Systematic Reviews and Meta-Analyses: The PRISMA Statement. PLoS Med 6(7): e1000097. https://doi.org/10.1371/journal.pmed.1000097

Pamer, E. G. (2016). Resurrecting the intestinal microbiota to combat antibiotic-resistant pathogens. Science, 352(6285), 535-538. doi: 10.1126/science.aad9382

Pew Research Center. (2016). Antibiotic Use in Outpatient Settings [PDF file]. Retrieved from https://www.pewtrusts.org//media/assets/2016/05/antibioticuseinoutpatientsettings .pdf 
Van Boeckel, T., Gandra, S., Ashok, A., Caudron, Q., Grenfell, B., Levin, S., \& Laxminarayan, R. (2014, August). Global antibiotic consumption 2000 to 2010: An analysis of national pharmaceutical sales data. Retrieved April 14, 2020, from https://www.ncbi.nlm.nih.gov/pubmed/25022435

Ventola C. L. (2015). The antibiotic resistance crisis: part 1: causes and threats. Pharmacy and Therapeutics: a peer reviewed journal for formulary management, 40(4), 277-283.

World Health Organization. (2020, May 28). Drug-resistant tuberculosis. https://www.who.int/tb/areas-of-work/drug-resistant-tb/en/

World Health Organization. (2018, November 12). Wide differences in antibiotic use between countries, according to new data from the World Health Organization. https://www.who.int/medicines/areas/rational_use/oms-amr-amc-report20162018 $\underline{\text { media-note/en/ }}$ 


\section{Appendix A1}

\section{Four-phase flow diagram}

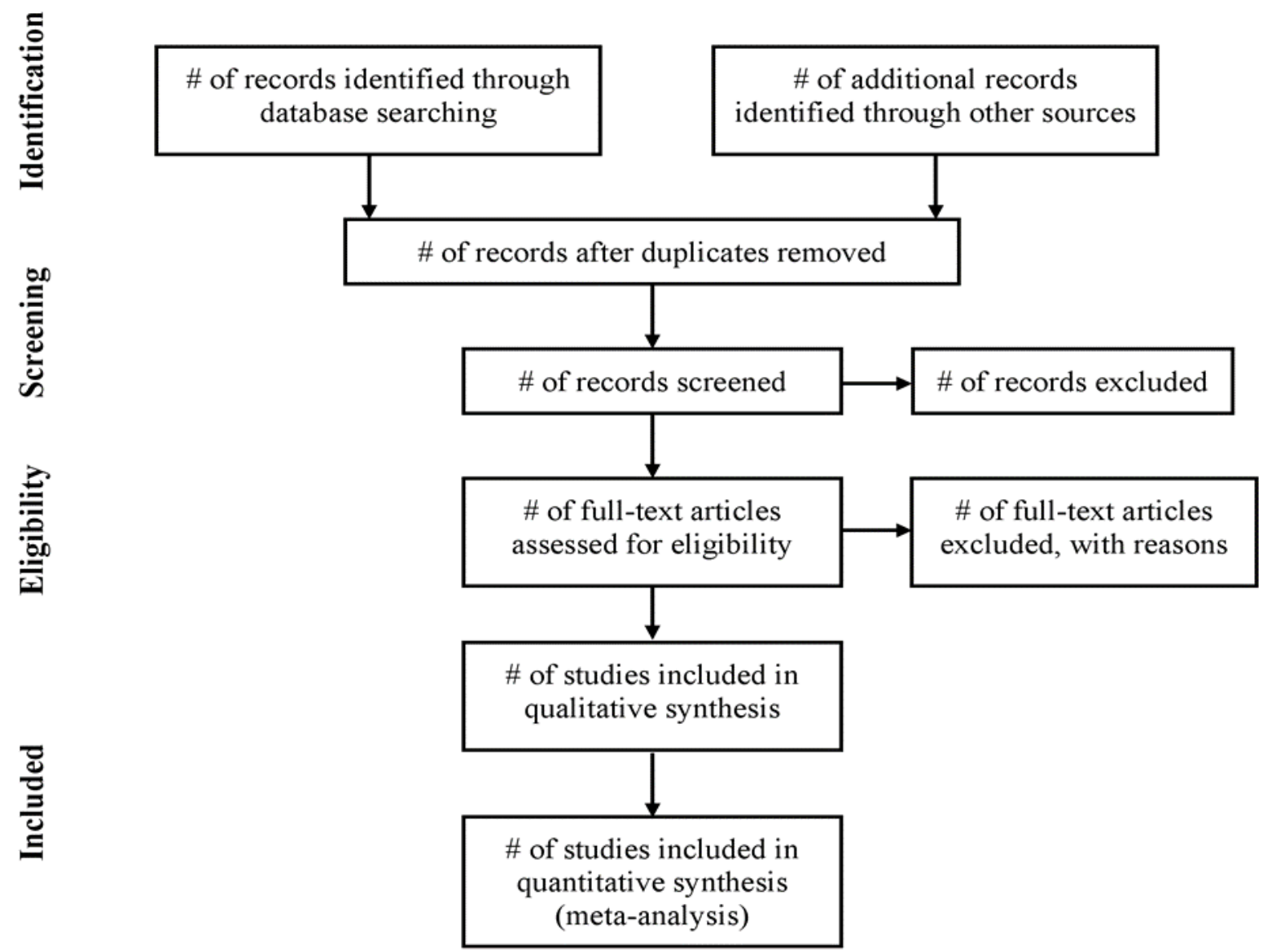




\section{Appendix A2}

PRISMA 2009 Flow Diagram

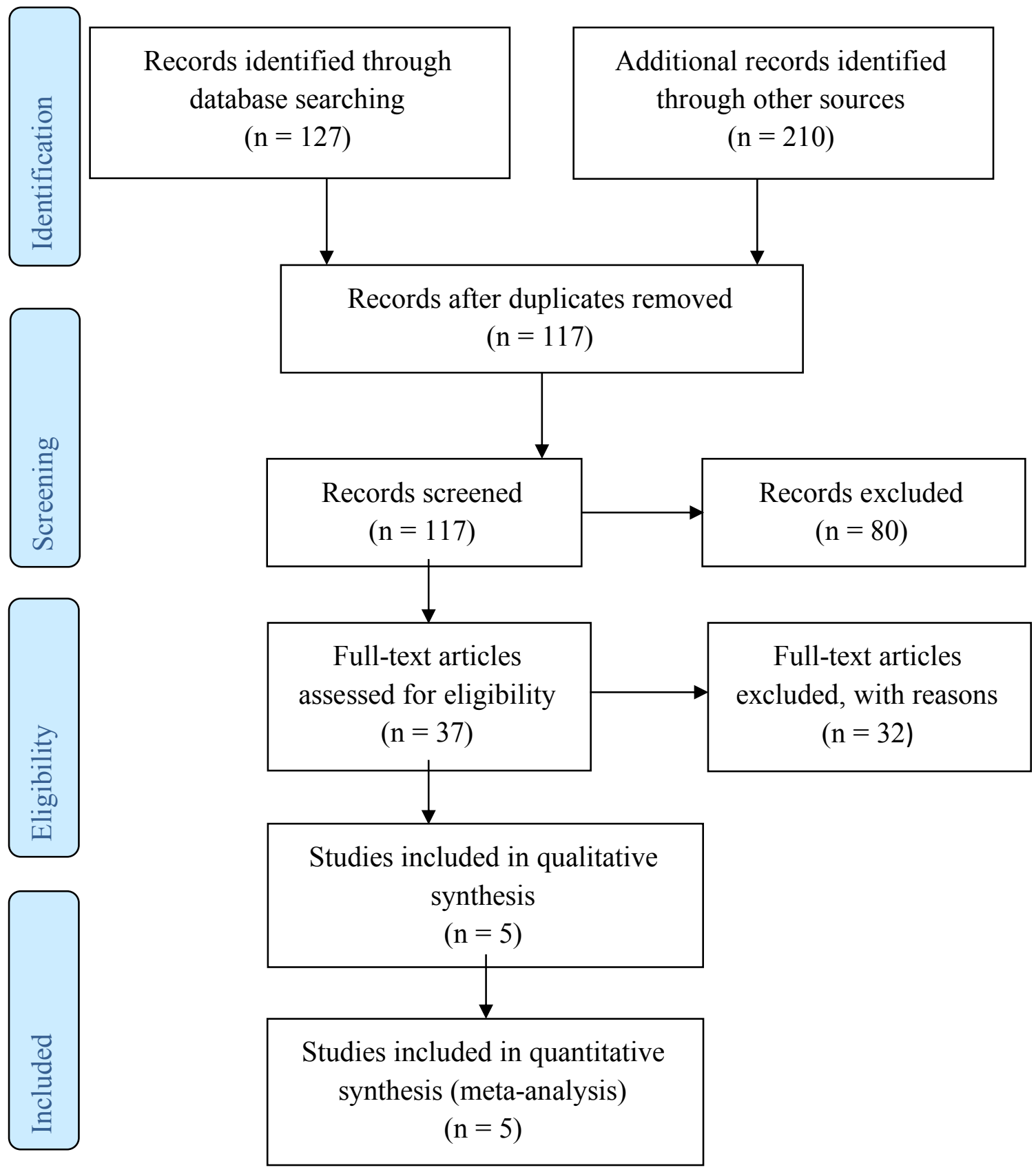




\section{Appendix B}

PRISMA 27 Item checklist:

\begin{tabular}{|c|c|c|c|}
\hline Section/topic & $\#$ & Checklist item & $\begin{array}{l}\text { Reported } \\
\text { on page } \\
\#\end{array}$ \\
\hline \multicolumn{4}{|l|}{ TITLE } \\
\hline Title & 1 & Identify the report as a s/stematic review, meta-analysis, or both. & \\
\hline \multicolumn{4}{|l|}{ ABSTRACT } \\
\hline $\begin{array}{l}\text { Structured } \\
\text { summary }\end{array}$ & 2 & $\begin{array}{l}\text { Provide a structured summany including, as applicable: background; objectives; data } \\
\text { sources; study eligbility criteria, participants, and interventions; sudy appraisal and } \\
\text { s/nthesis methods; results; imitations; conclusions and implications of key findings; } \\
\text { s/stematic review registration number. }\end{array}$ & \\
\hline \multicolumn{4}{|c|}{ INTRODUCTION } \\
\hline Rationale & 3 & Describe the rationale for the review in the cortext of what is already known. & \\
\hline Objectives & 4 & $\begin{array}{l}\text { Provide an explict statement of questions being addressed with reference to participants, } \\
\text { interventions, comparisons, outcomes, and study design (PCOS). }\end{array}$ & \\
\hline \multicolumn{4}{|l|}{ METHODS } \\
\hline $\begin{array}{l}\text { Protocoland } \\
\text { registration }\end{array}$ & 5 & $\begin{array}{l}\text { Indicate if a review protocol exists, if and where it can be accessed (e.g., Web address), } \\
\text { and, if arailable, provide registration information including registration number. }\end{array}$ & \\
\hline $\begin{array}{l}\text { Eligibility } \\
\text { criteria }\end{array}$ & 6 & $\begin{array}{l}\text { Specify study characteristics (e.g., PICOS, length of follow-up) and report characteristics } \\
\text { (e.g., years considered, language, publication status) used as criteria for eligibility, giving } \\
\text { rationale. }\end{array}$ & \\
\hline $\begin{array}{l}\text { Information } \\
\text { sources }\end{array}$ & 7 & $\begin{array}{l}\text { Describe all information sources (e.g, databases with dates of coverage, contact with study } \\
\text { authors to identify additional suddies) in the search and date last searched. }\end{array}$ & \\
\hline Search & 8 & $\begin{array}{l}\text { Presentf full electronic search strategy for at least one database, including any limits used, } \\
\text { such that it could be repeated. }\end{array}$ & \\
\hline Study selection & 9 & $\begin{array}{l}\text { State the process for selecting studies (i.e., screening, eligibility, included in s/stematic } \\
\text { review, and, if applicable, included in the meta-analysis). }\end{array}$ & \\
\hline $\begin{array}{l}\text { Data collection } \\
\text { process }\end{array}$ & 10 & $\begin{array}{l}\text { Describe method of data extraction from reports (e.g., pilded forms, independently, in } \\
\text { duplicate) and any processes for obtaining and confirming datafifom investigators }\end{array}$ & \\
\hline Data items & 11 & $\begin{array}{l}\text { List and define all variables for which data were sought (e.g., PICOS, funding sources) and } \\
\text { any assumptions and simplifications made. }\end{array}$ & \\
\hline $\begin{array}{l}\text { Risk of bias in } \\
\text { individual } \\
\text { studies }\end{array}$ & 12 & $\begin{array}{l}\text { Describe methods used for assessing risk of bias of individual studies (including } \\
\text { specification of whether this was done at the sudy or outcome level), and how this } \\
\text { information is to be used in any data synthesis. }\end{array}$ & \\
\hline $\begin{array}{l}\text { Summary } \\
\text { measures }\end{array}$ & 13 & State the principal summary measures (e.g., risk ratio, difference in means). & \\
\hline $\begin{array}{l}\text { Synthesis of } \\
\text { results }\end{array}$ & 14 & $\begin{array}{l}\text { Describe the methods of handling data and combining results of studies, if done, including } \\
\text { measures of consistency (e.g., 12) for each meta-analysis. }\end{array}$ & \\
\hline
\end{tabular}




\begin{tabular}{|c|c|c|c|}
\hline Section/topic & $\#$ & Checklist item & $\begin{array}{l}\text { Reported } \\
\text { on page\# }\end{array}$ \\
\hline $\begin{array}{l}\text { Risk of bias } \\
\text { across studies }\end{array}$ & 15 & $\begin{array}{l}\text { Speciffy any assessment of risk of bias that may affect the cumulative evidence } \\
\text { (e.g., publication bias, selective reporting within studies). }\end{array}$ & \\
\hline $\begin{array}{l}\text { Addtional } \\
\text { analyses }\end{array}$ & 16 & $\begin{array}{l}\text { Describe methods of additional analyses (e.g., sensitivity or subgroup analyses, } \\
\text { meta-regression), if done, indic ating which were pre-specified. }\end{array}$ & \\
\hline \multicolumn{3}{|l|}{ RESULTS } & \\
\hline Study selection & 17 & $\begin{array}{l}\text { Give numbers of studies screened, assessed for eligibility, and included in the } \\
\text { review, with reasons for exclusions at each stage, ideally with a flow diagram. }\end{array}$ & \\
\hline $\begin{array}{l}\text { Study } \\
\text { characteristics }\end{array}$ & 18 & $\begin{array}{l}\text { For each study, present characteristics for which data were extracted (e.g., study } \\
\text { size, PICOS, follow-up period) and provide the citations. }\end{array}$ & \\
\hline $\begin{array}{l}\text { Risk of bias } \\
\text { within studies }\end{array}$ & 19 & $\begin{array}{l}\text { Present data on risk of bias of each study and, if available, any outcome level } \\
\text { assessment (see tem 12). }\end{array}$ & \\
\hline $\begin{array}{l}\text { Results of } \\
\text { individual } \\
\text { studies }\end{array}$ & 20 & $\begin{array}{l}\text { For all outcomes considered (benefits or harms), present, for each study: (a) } \\
\text { simple summary data for each intervention group (b) effect estimates and } \\
\text { confidence intervals, ideally with a forest plot. }\end{array}$ & \\
\hline $\begin{array}{l}\text { Synthesis of } \\
\text { results }\end{array}$ & 21 & $\begin{array}{l}\text { Present results of each meta-analysis done, including confidence intervals and } \\
\text { measures of consistency. }\end{array}$ & \\
\hline $\begin{array}{l}\text { Risk of bias } \\
\text { across studies }\end{array}$ & 22 & Present results of any assessment of risk of bias across studies (see ltem 15). & \\
\hline $\begin{array}{l}\text { Additional } \\
\text { analysis }\end{array}$ & 23 & $\begin{array}{l}\text { Give results of additional analyses, if done (e.g., sensitivity or subgroup } \\
\text { analyses, meta-regression [see ltem 16]). }\end{array}$ & \\
\hline \multicolumn{3}{|l|}{ DISCUSSION } & \\
\hline $\begin{array}{l}\text { Summary of } \\
\text { evidence }\end{array}$ & 24 & $\begin{array}{l}\text { Summarize the main findings including the strength of evidence for each main } \\
\text { outcome; consider their relevance to key groups (e.g., healthcare providers, } \\
\text { users, and policy makers). }\end{array}$ & \\
\hline Limitations & 25 & $\begin{array}{l}\text { Discuss limitations at study and outcome level (e.g., risk of bias), and at review- } \\
\text { level (e.g., incomplete retrieval of identified research, reporting bias). }\end{array}$ & \\
\hline Conclusions & 26 & $\begin{array}{l}\text { Provide a general interpretation of the results in the context of other evidence, } \\
\text { and implications for future research. }\end{array}$ & \\
\hline \multicolumn{3}{|l|}{ FUNDING } & \\
\hline Funding & 27 & $\begin{array}{l}\text { Describe sources of funding for the s/stematic review and other support (e.g., } \\
\text { supply of data); role of funders for the s/stematic review. }\end{array}$ & \\
\hline
\end{tabular}




\section{Appendix C1}

Butler, C. C., Simpson, S. A., Dunstan, F., Rollnick, S., Cohen, D., Gillespie, D., ... Hood, K. (2012). Effectiveness of multifaceted educational programme to reduce antibiotic dispensing in primary care: practice based randomised controlled trial. British Medical Journal, 344(feb02 1), d8173-d8173. doi: 10.1136/bmj.d8173

\begin{tabular}{|c|c|c|c|c|}
\hline AIM/PURPOSE & DESIGN & $\underline{\text { SAMPLE }}$ & $\underline{\text { METHODS }}$ & OUTCOMES \\
\hline $\begin{array}{l}\text { Evaluate the } \\
\text { effectiveness } \\
\text { and costs of a } \\
\text { multifaceted } \\
\text { flexible } \\
\text { educational } \\
\text { program aimed } \\
\text { at reducing } \\
\text { antibiotic } \\
\text { dispensing at } \\
\text { the practice } \\
\text { level in primary } \\
\text { care. }\end{array}$ & $\begin{array}{l}\text { Randomized controlled trial } \\
\text { with general practices to } \\
\text { intervention or control. } \\
\text { Patients can be managed by any of } \\
\text { the providers in the practice so the } \\
\text { practice was considered as the unit } \\
\text { for randomization and analysis. } \\
\text { Dynamic block allocation achieved } \\
\text { balance between group of practices } \\
\text { for rate of antibiotic dispensing, } \\
\text { practice size and proportion of } \\
\text { clinicians. Practices then divided } \\
\text { into three sets of } 24,22 \text { and } 22 \\
\text { practices and each set allocated } \\
\text { into two groups. All blinded to } \\
\text { group allocation until after } \\
\text { randomization. } \\
68 \text { general practices with } 480,00 \\
\text { patients }\end{array}$ & $\begin{array}{l}34 \text { practices } \\
\text { randomized } \\
\text { to receive } \\
\text { the } \\
\text { educational } \\
\text { program } \\
\text { with } 139 \\
\text { clinicians } \\
34 \text { practices } \\
\text { to be } \\
\text { control with } \\
124 \\
\text { clinicians }\end{array}$ & $\begin{array}{l}\text { Stemming the Tide } \\
\text { of Antibiotic } \\
\text { Resistance } \\
\text { (STAR) } \\
\text { educational } \\
\text { program } \\
\text { implemented a } \\
\text { practice-based } \\
\text { seminar reflecting } \\
\text { on the practices' } \\
\text { own dispensing } \\
\text { and resistance } \\
\text { data, online } \\
\text { educational } \\
\text { elements, and } \\
\text { practicing } \\
\text { consulting skills in } \\
\text { routine care. } \\
\text { Control practices } \\
\text { provided usual } \\
\text { care. }\end{array}$ & $\begin{array}{l}\text { The rate of oral antibiotic dispensing } \\
\text { decreased by } 14.1 \text { per } 1000 \text { in the } \\
\text { intervention group, increased by } 12.1 \text { per } \\
1000 \text { in the control group, a net } \\
\text { difference of } 26.2 \text { per } 1000 \text {. } \\
\text { A } 4.2 \% \text { ( } 95 \% \text { confidence interval } 0.6 \% \\
\text { to } 7.7 \% \text { ) reduction in oral antibiotic } \\
\text { dispensing for the year in the } \\
\text { intervention group relative to the control } \\
\text { group ( } \mathrm{P}=0.02) \\
\text { No significant differences between } \\
\text { intervention/control practices in the } \\
\text { number of admissions to hospital, } \\
\text { consultations for a respiratory tract } \\
\text { infection within seven days }\end{array}$ \\
\hline
\end{tabular}




\section{Appendix C2}

\begin{tabular}{|c|c|c|c|c|}
\hline \\
\hline \multicolumn{5}{|c|}{$\begin{array}{l}\text { Gerber, J. S., Prasad, P. A., Fiks, A. G., Localio, A. R., Grundmeier, R. W., Bell, L. M., ... Zaoutis, T. E. (2013). Effect of an outpatient } \\
\text { antimicrobial stewardship intervention on broad-spectrum antibiotic prescribing by primary care pediatricians. Journal of the } \\
\text { American Medical Association, 309(22), 2345-2352. doi: } 10.1001 / \text { jama.2013.6287 } \\
\text { AIM/PURPOSE DESIGN }\end{array}$} \\
\hline $\begin{array}{l}\text { Evaluate the } \\
\text { efficacy of an } \\
\text { antimicrobial } \\
\text { stewardship } \\
\text { intervention } \\
\text { prescribing for } \\
\text { pediatric } \\
\text { outpatients. }\end{array}$ & $\begin{array}{l}\text { Cluster randomized trial } \\
\text { by block-randomized } \\
\text { practices (clusters) by } \\
\text { location and volume. The } \\
\text { unit of observation was the } \\
\text { provider but randomized at } \\
\text { practice level to avoid } \\
\text { intra-practice } \\
\text { contamination of the } \\
\text { intervention. } \\
\text { Outpatient antimicrobial } \\
\text { stewardship comparing } \\
\text { prescribing between } \\
\text { intervention and control } \\
\text { practices using a common } \\
\text { electronic health record. }\end{array}$ & $\begin{array}{l}25 \text { pediatric primary } \\
\text { care practices } \\
\text { Of } 20 \text { eligible } \\
\text { practices } 18 \text { agreed } \\
\text { to participate }\end{array}$ & $\begin{array}{l}\text { Intervention } \\
\text { included clinician } \\
\text { education } \\
\text { coupled with } \\
\text { audit and } \\
\text { feedback of an } \\
\text { antibiotic } \\
\text { prescribing to } \\
\text { children with } \\
\text { ARTIs } \\
\text { Control with no } \\
\text { interventions }\end{array}$ & $\begin{array}{l}\text { Broad-spectrum prescribing decreased from } \\
26.8 \% \text { to } 14.3 \% \text { among intervention } \\
\text { practices vs from } 28.4 \% \text { to } 22.6 \% \text {. } \\
\text { Off-guideline prescribing for children with } \\
\text { pneumonia decreased from } 15.7 \% \text { to } 4.2 \% \\
\text { among intervention practices compared } \\
\text { with } 17.1 \% \text { to } 16.3 \% \text { and for acute sinusitis } \\
\text { from } 39.8 \% \text { to } 18.8 \% \text {. } \\
\text { Off-guideline prescribing was uncommon } \\
\text { at baseline and changed little for } \\
\text { streptococcal pharyngitis (intervention } \\
\text { from } 4.4 \% \text { to } 3.4 \% \text {; control from } 5.6 \% \text { to } \\
3.5 \% \text { ) and for viral infections }(7.9 \% \text { to } \\
7.7 \% \text {; control, from } 6.4 \% \text { to } 4.5 . \%) \text {. }\end{array}$ \\
\hline
\end{tabular}




\section{Appendix C3}

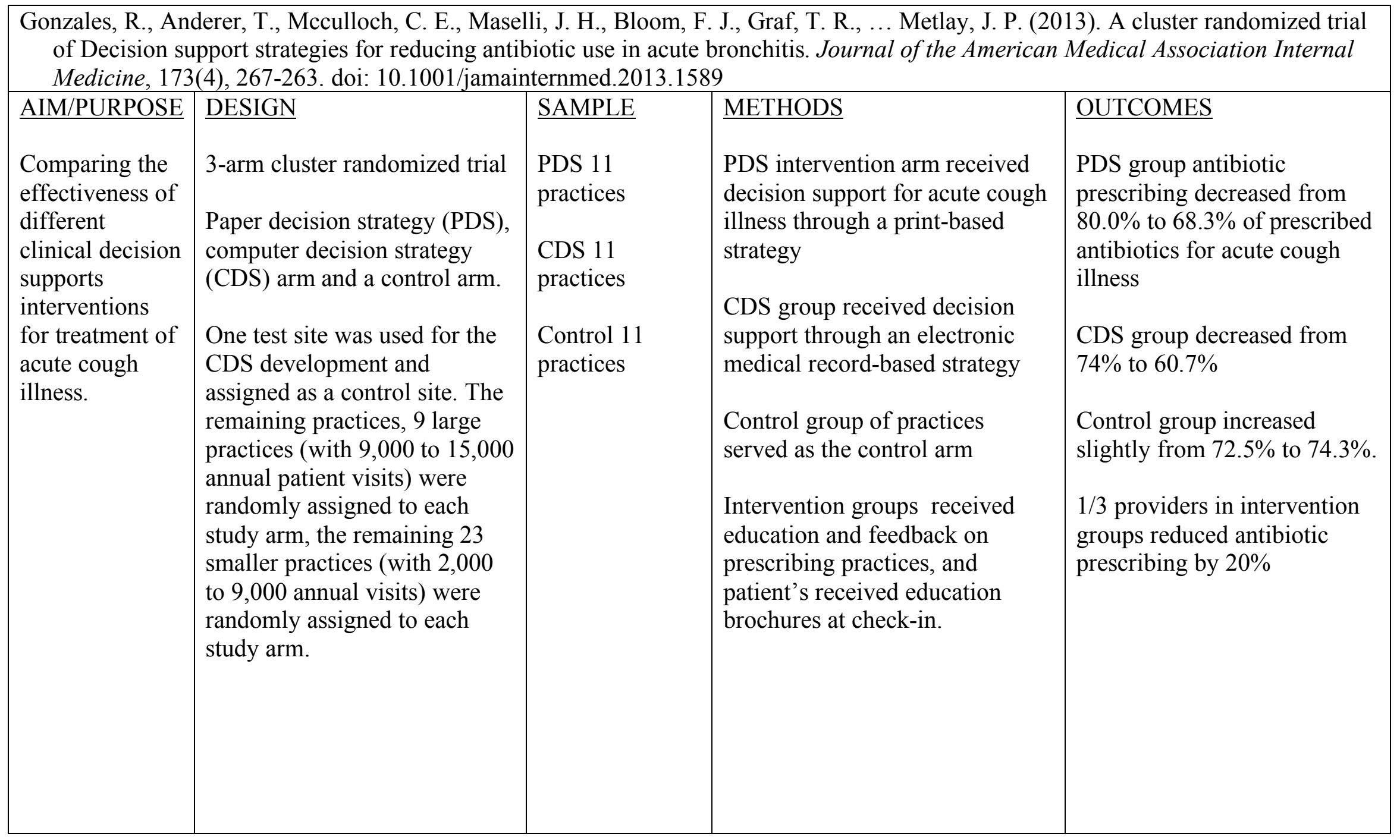




\section{Appendix C4}

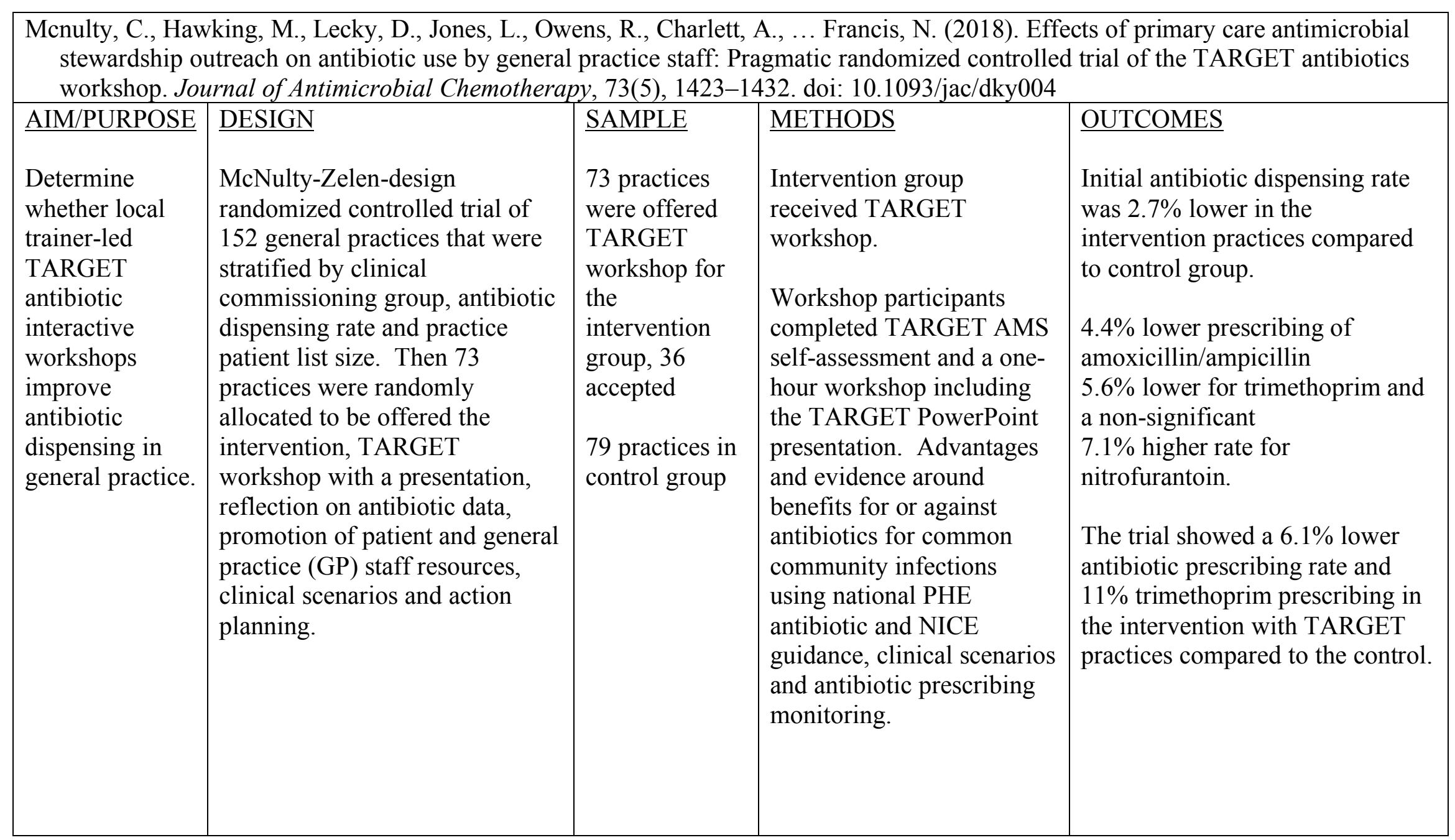




\section{Appendix C5}

\begin{tabular}{|c|c|c|c|c|}
\hline \multicolumn{5}{|c|}{$\begin{array}{l}\text { Légaré, F., Labrecque, M., Leblanc, A., Njoya, M., Laurier, C., Côté, L., ... St-Jacques, S. (2010). Training family physicians in } \\
\text { shared decision making for the use of antibiotics for acute respiratory infections: A pilot clustered randomized controlled trial. } \\
\text { Health Expectations, 14, 96-110. doi: } 10.1111 / j .1369-7625.2010 .00616 . x\end{array}$} \\
\hline AIM/PURPOSE & DESIGN & $\underline{\text { SAMPLE }}$ & METHODS & OUTCOMES \\
\hline $\begin{array}{l}\text { To develop, adapt } \\
\text { and validate } \\
\text { DECISION+ and } \\
\text { estimate its impact } \\
\text { on decision of } \\
\text { family physicians } \\
\text { and their patients } \\
\text { on whether to use } \\
\text { antibiotics for } \\
\text { ARIs. }\end{array}$ & $\begin{array}{l}\text { Two-arm parallel } \\
\text { clustered pilot } \\
\text { randomized controlled } \\
\text { trial. } \\
\text { A biostatistician } \\
\text { simultaneously } \\
\text { randomized four family } \\
\text { medicine groups to } \\
\text { immediate DECISION+ } \\
\text { participation (the } \\
\text { experimentation of the } \\
\text { group) or delayed } \\
\text { DECISION+ } \\
\text { participation (the } \\
\text { control group). }\end{array}$ & $\begin{array}{l}4 \text { of } 21 \text { eligible } \\
\text { family medical } \\
\text { groups (FMGs) } \\
\text { enrolled } \\
2 \text { FMGs with } 18 \\
\text { family practitioners } \\
\text { (FPs) and } 245 \\
\text { patients in } \\
\text { experimental group } \\
2 \text { FMGs with } 15 \\
\text { FPs and } 214 \\
\text { patients in control } \\
\text { group }\end{array}$ & $\begin{array}{l}\text { DECISION+, } \\
\text { workshops and } \\
\text { training were } \\
\text { provided to FPs. } \\
\text { Two weeks after } \\
\text { the initial } \\
\text { consultation, } \\
\text { patients' } \\
\text { adherence to the } \\
\text { decision, repeat } \\
\text { consultation, } \\
\text { decisional regret } \\
\text { and quality of life } \\
\text { was assessed. } \\
\text { Control group } \\
\text { providers were } \\
\text { given } \\
\text { DECISION+ } 6 \\
\text { months later. }\end{array}$ & $\begin{array}{l}\text { In the experimental group, } 21 \% \text { fewer } \\
\text { patients decided to use antibiotics } \\
\text { immediately and the control group only } \\
8 \% \text {. } \\
\text { The percentage of patients who decided to } \\
\text { use antibiotics after consultation was } \\
52.2 \% \text { in the control group and } 27.2 \% \text { in } \\
\text { the experimental group (absolute difference } \\
25.0 \% \text {, adjusted relative risk } 0.48,95 \% \\
\text { confidence interval } 0.34-0.68 \text { ). } \\
\text { DECISION+ was associated with patients } \\
\text { taking a more active role in decision- } \\
\text { making and reported outcomes } 2 \text { weeks } \\
\text { after consultation were similar in both } \\
\text { groups. }\end{array}$ \\
\hline
\end{tabular}




\section{Appendix D1}

Butler, C. C., Simpson, S. A., Dunstan, F., Rollnick, S., Cohen, D., Gillespie, D., ... Hood, K. (2012). Effectiveness of multifaceted educational programme to reduce antibiotic dispensing in primary care: practice based randomised controlled trial. British Medical Journal, 344(feb02 1), d8173-d8173. doi: 10.1136/bmj.d8173

\begin{tabular}{|c|c|c|c|}
\hline Section A: Are the results of the trial valid? & Yes & $\begin{array}{c}\text { Can't } \\
\text { tell }\end{array}$ & No \\
\hline 1. Did the trial address a clearly focused issue? & $\mathrm{X}$ & & \\
\hline 2. Was the assignment of interventions randomized? & $\mathrm{X}$ & $\mathrm{X}$ & \\
\hline $\begin{array}{c}\text { 3. Were all of the participants who entered the trial } \\
\text { properly accounted for at its conclusion? }\end{array}$ & $\mathrm{X}$ \\
\hline $\begin{array}{c}\text { 4. Were patients, health workers and study personnel } \\
\text { blind' to treatment? }\end{array}$ & & $\mathrm{X}$ & \\
\hline $\begin{array}{l}\text { 5. Were the groups similar at the start of the trial? } \\
\text { 6. Aside from the experimental intervention, were the } \\
\text { groups treated equally? }\end{array}$ & $\mathrm{X}$ & & \\
\hline
\end{tabular}

Section B: What are the results?

7. How large was the intervention effect?

The rate of oral antibiotic dispensing (items per 1000 registered patients) decreased by 14.1 per 1000 in the intervention group but increased by 12.1 per 1000 in the control group, a net difference of 26.1 per 1000.

8 . How precise was the estimate of the intervention effect? A 4.2\% (95\% confidence interval $0.6 \%$ to $7.7 \%$ ) reduction in total oral antibiotic dispensing for the year in the intervention group relative to the control group $(P=0.02)$.

\begin{tabular}{|c|c|c|c|}
\hline Section C: Will the results help locally? & Yes & $\begin{array}{c}\text { Can't } \\
\text { tell }\end{array}$ & No \\
\hline $\begin{array}{c}\text { 9. Can the results be applied to the local population, or in } \\
\text { your context? }\end{array}$ & $\mathrm{X}$ & & \\
\hline 10. Were all important outcomes considered? & $\mathrm{X}$ & & \\
\hline 11. Are the benefits worth the harms and costs? & $\mathrm{X}$ & & \\
\hline
\end{tabular}

Critical Appraisal Skills Programme (CASP) Randomised Controlled Trials Checklist (2013) 


\section{Appendix D2}

Gerber, J. S., Prasad, P. A., Fiks, A. G., Localio, A. R., Grundmeier, R. W., Bell, L. M., ... Zaoutis, T. E. (2013). Effect of an outpatient antimicrobial stewardship intervention on broad-spectrum antibiotic prescribing by primary care pediatricians. Journal of the American Medical Association, 309(22), 2345-2352. doi: 10.1001/jama.2013.6287

\begin{tabular}{|c|c|c|c|}
\hline Section A: Are the results of the trial valid? & Yes & $\begin{array}{c}\text { Can't } \\
\text { tell }\end{array}$ & No \\
\hline 1. Did the trial address a clearly focused issue? & $\mathrm{X}$ & & \\
\hline 2. Was the assignment of interventions randomized? & $\mathrm{X}$ & & \\
\hline $\begin{array}{l}\text { 3. Were all of the participants who entered the trial } \\
\text { properly accounted for at its conclusion? }\end{array}$ & $\mathrm{X}$ & & \\
\hline $\begin{array}{l}\text { 4. Were patients, health workers and study personnel } \\
\text { 'blind' to treatment? }\end{array}$ & & $\mathrm{X}$ & \\
\hline 5. Were the groups similar at the start of the trial? & $\mathrm{X}$ & & \\
\hline $\begin{array}{l}\text { 6. Aside from the experimental intervention, were the } \\
\text { groups treated equally? }\end{array}$ & $\mathrm{X}$ & & \\
\hline
\end{tabular}

Section B: What are the results?

7. How large was the intervention effect?

Broad-spectrum antibiotic prescribing decreased from $26.8 \%$ to $14.3 \%$ (absolute difference, $12.5 \%$ ) among intervention practices vs from $28.4 \%$ to $22.6 \%$ (absolute difference, $5.8 \%$ ) in controls

8. How precise was the estimate of the intervention effect?

The difference between groups was significant considering the changes in trajectories of broad-spectrum prescribing before and during the intervention between the 2 groups of practices $(P=.01)$

\begin{tabular}{|l|c|c|c|}
\hline Section C: Will the results help locally? & Yes & $\begin{array}{c}\text { Can't } \\
\text { tell }\end{array}$ & No \\
$\begin{array}{l}\text { 9. Can the results be applied to the local population, or in } \\
\text { your context? }\end{array}$ & $\mathrm{X}$ & & \\
\hline $\begin{array}{l}\text { 10. Were all important outcomes considered? } \\
\text { 11. Are the benefits worth the harms and costs? }\end{array}$ & $\mathrm{X}$ & & \\
\hline
\end{tabular}

Critical Appraisal Skills Programme (CASP) Randomised Controlled Trials Checklist (2013) 


\section{Appendix D3}

\begin{tabular}{|l|c|c|c|}
\hline $\begin{array}{l}\text { Gonzales, R., Anderer, T., Mcculloch, C. E., Maselli, J. H., Bloom, F. J., Graf, T. R., } \\
\text {.. Metlay, J. P. (2013). A cluster randomized trial of Decision support strategies for } \\
\text { reducing antibiotic use in acute bronchitis. Journal of the American Medical } \\
\text { Association Internal Medicine, 173(4), 267-263. doi: } \\
\text { 10.1001/jamainternmed.2013.1589 }\end{array}$ & Yes & $\begin{array}{c}\text { Can't } \\
\text { tell }\end{array}$ & No \\
\hline Section A: Are the results of the trial valid? & $\mathrm{X}$ & & \\
\hline 1. Did the trial address a clearly focused issue? & $\mathrm{X}$ & & \\
\hline $\begin{array}{l}\text { 2. Was the assignment of interventions randomized? } \\
\text { 3. Were all of the participants properly accounted for at its } \\
\text { conclusion? }\end{array}$ & $\mathrm{X}$ & & \\
\hline $\begin{array}{l}\text { 4. Were patients, health workers and study personnel } \\
\text { 'blind' to treatment? }\end{array}$ & & $\mathrm{X}$ & \\
\hline $\begin{array}{l}\text { 5. Were the groups similar at the start of the trial? } \\
\text { 6. Aside from the experimental intervention, were the } \\
\text { groups treated equally? }\end{array}$ & $\mathrm{X}$ & & \\
\hline Sely
\end{tabular}

Section B: What are the results?

7. How large was the intervention effect?

Prescribed antibiotics during intervention period decreased at PDS sites (from $80.0 \%$ to $68.3 \%$ ) at CDS sites (from $74.0 \%$ to $60.7 \%$ ) but increased slightly at the control sites (from $72.5 \%$ to $74.3 \%$ )

8. How precise was the estimate of the intervention effect?

Differences for intervention sites from control sites $(P=.003$ for control sites vs $P D S$ intervention sites and $P=.01$ for control sites vs CDS intervention sites) between themselves ( $P=.67$ for PDS intervention sites vs CDS intervention sites).

\begin{tabular}{|c|c|c|c|}
\hline Section C: Will the results help locally? & Yes & $\begin{array}{c}\text { Can't } \\
\text { tell }\end{array}$ & No \\
\hline $\begin{array}{c}\text { 9. Can the results be applied to the local population, or in } \\
\text { your context? }\end{array}$ & $\mathrm{X}$ & & \\
\hline 10. Were all important outcomes considered? & $\mathrm{X}$ & & \\
\hline 11. Are the benefits worth the harms and costs? & $\mathrm{X}$ & & \\
\hline
\end{tabular}

Critical Appraisal Skills Programme (CASP) Randomised Controlled Trials Checklist (2013) 


\section{Appendix D4}

McNulty, C., Hawking, M., Lecky, D., Jones, L., Owens, R., Charlett, A., ... Francis, N. (2018). Effects of primary care antimicrobial stewardship outreach on antibiotic use by general practice staff: pragmatic randomized controlled trial of the TARGET antibiotics workshop. Journal of Antimicrobial Chemotherapy, 73(5), 1423-1432. doi: 10.1093/jac/dky004

\begin{tabular}{|c|c|c|c|}
\hline Section A: Are the results of the trial valid? & Yes & $\begin{array}{c}\text { Can't } \\
\text { tell }\end{array}$ & No \\
\hline 1. Did the trial address a clearly focused issue? & $\mathrm{X}$ & & \\
\hline 2. Was the assignment of interventions randomized? & $\mathrm{X}$ & & \\
\hline $\begin{array}{l}\text { 3. Were all of the participants properly accounted for at its } \\
\text { conclusion? }\end{array}$ & $\mathrm{X}$ & & $\mathrm{X}$ \\
$\begin{array}{l}\text { 4. Were patients, health workers and study personnel } \\
\text { blind' to treatment? }\end{array}$ & $\mathrm{X}$ & & \\
\hline $\begin{array}{l}\text { 5. Were the groups similar at the start of the trial? } \\
\text { 6. Aside from the experimental intervention, were the } \\
\text { groups treated equally? }\end{array}$ & $\mathrm{X}$ & & \\
\hline
\end{tabular}

Section B: What are the results?

7. How large was the intervention effect?

CACE analysis showed that practices that comply with assigned intervention, indicated $6.1 \%$ lower total antibiotic dispensing in intervention practices and $11 \%$ lower trimethoprim dispensing.

8. How precise was the estimate of the intervention effect?

CACE analysis of those that comply with assigned intervention (95\% CI $0.2 \%-11.7 \%$, $P=0.04)$ for total antibiotic dispensing in intervention practices and $(95 \% \mathrm{CI} 1.6 \%$ $19.5 \%, P=0.02)$ for trimethoprim dispensing.

\begin{tabular}{|c|c|c|c|}
\hline Section C: Will the results help locally? & Yes & $\begin{array}{c}\text { Can't } \\
\text { tell }\end{array}$ & No \\
\hline $\begin{array}{c}\text { 9. Can the results be applied to the local population, or in } \\
\text { your context? }\end{array}$ & $\mathrm{X}$ & & \\
\hline 10. Were all important outcomes considered? & $\mathrm{X}$ & & \\
\hline 11. Are the benefits worth the harms and costs? & $\mathrm{X}$ & & \\
\hline
\end{tabular}

Critical Appraisal Skills Programme (CASP) Randomised Controlled Trials Checklist (2013) 


\section{Appendix D5}

\begin{tabular}{|l|c|c|c|}
\hline $\begin{array}{l}\text { Légaré, F., Labrecque, M., Leblanc, A., Njoya, M., Laurier, C., Côté, L., .. St-Jacques, } \\
\text { S. (2010). Training family physicians in shared decision making for the use of } \\
\text { antibiotics for acute respiratory infections: a pilot clustered randomized controlled } \\
\text { trial. Health Expectations, 14, 96-110. doi: 10.1111/j.1369-7625.2010.00616.x }\end{array}$ \\
\hline Section A: Are the results of the trial valid? & Yes & $\begin{array}{c}\text { Can't } \\
\text { tell }\end{array}$ & No \\
\hline 1. Did the trial address a clearly focused issue? & $\mathrm{X}$ & & \\
\hline 2. Was the assignment of interventions randomized? & $\mathrm{X}$ & & \\
\hline $\begin{array}{c}\text { 3. Were all of the participants of the trial properly } \\
\text { accounted for at its conclusion? }\end{array}$ & & & $\mathrm{X}$ \\
\hline $\begin{array}{c}\text { 4. Were patients, health workers and study personnel } \\
\text { 'blind' to treatment? }\end{array}$ & & $\mathrm{X}$ & \\
\hline $\begin{array}{l}\text { 5. Were the groups similar at the start of the trial? } \\
\text { 6. Aside from the experimental intervention, were the } \\
\text { groups treated equally? }\end{array}$ & $\mathrm{X}$ & & \\
\hline Secti. B. Whe & & & \\
\hline
\end{tabular}

Section B: What are the results?

7. How large was the intervention effect?

Percentage of patients who decided to use antibiotics after consultation was $52.2 \%$ in the control group and $27.2 \%$ in the DECISION+ group

8. How precise was the estimate of the intervention effect?

Absolute difference $25.0 \%$, adjusted relative risk $0.48,95 \%$ confidence interval 0.34 0.68

\begin{tabular}{|l|c|c|c|}
\hline Section C: Will the results help locally? & Yes & $\begin{array}{c}\text { Can't } \\
\text { tell }\end{array}$ & No \\
\hline $\begin{array}{c}\text { 9. Can the results be applied to the local population, or in } \\
\text { your context? }\end{array}$ & $\mathrm{X}$ & & \\
\hline 10. Were all important outcomes considered? & $\mathrm{X}$ & & \\
\hline 11. Are the benefits worth the harms and costs? & $\mathrm{X}$ & & \\
\hline
\end{tabular}

Critical Appraisal Skills Programme (CASP) Randomised Controlled Trials Checklist (2013) 


\section{Appendix E}

Cross study analysis table

\begin{tabular}{|c|c|c|}
\hline Study & Intervention & Outcomes \\
\hline $\begin{array}{l}\text { Study } 1 \\
\text { (Butler et } \\
\text { al., 2012) }\end{array}$ & $\begin{array}{l}\text { Stemming the Tide of Antibiotic } \\
\text { Resistance (STAR) educational } \\
\text { program included a practice- } \\
\text { based seminar reflecting on the } \\
\text { practices' own dispensing and } \\
\text { resistance data, online } \\
\text { educational elements, and } \\
\text { practicing consulting skills in } \\
\text { routine care for the experimental } \\
\text { group. }\end{array}$ & $\begin{array}{l}\text { Rate of oral antibiotic dispensing } \\
\text { decreased by } 14.1 \text { per } 1000 \text { in the } \\
\text { intervention group } \\
\text { Increased by } 12.1 \text { per } 1000 \text { in the } \\
\text { control group } \\
\text { Net difference of } 26.1 \text { per } 1000 \text {. }\end{array}$ \\
\hline $\begin{array}{l}\text { Study } 2 \\
\text { (Gerber et } \\
\text { al., 2013) }\end{array}$ & $\begin{array}{l}\text { Clinician education coupled with } \\
\text { audit and feedback of an } \\
\text { antibiotic prescribing to children } \\
\text { with ARTIs }\end{array}$ & $\begin{array}{l}\text { Broad-spectrum antibiotic } \\
\text { prescribing decreased from } 26.8 \% \text { to } \\
14.3 \% \text { among intervention practices } \\
\text { vs from } 28.4 \% \text { to } 22.6 \% \text {. } \\
\text { Off-guideline prescribing for } \\
\text { children with pneumonia decreased } \\
\text { from } 15.7 \% \text { to } 4.2 \% \text { among } \\
\text { intervention practices compared } \\
\text { with } 17.1 \% \text { to } 16.3 \% \text { and for acute } \\
\text { sinusitis from } 39.8 \% \text { to } 18.8 \% \text {. }\end{array}$ \\
\hline $\begin{array}{l}\text { Study } 3 \\
\text { (Gonzales et } \\
\text { al., 2013) }\end{array}$ & $\begin{array}{l}\text { PDS intervention arm received } \\
\text { decision support for acute cough } \\
\text { illness through a print-based } \\
\text { strategy } \\
\text { CDS group received decision } \\
\text { support through an electronic } \\
\text { medical record-based strategy } \\
\text { Control group of practices } \\
\text { served as the control arm } \\
\text { Intervention groups also } \\
\text { received education and feedback } \\
\text { on prescribing practices, and } \\
\text { patient education brochures at } \\
\text { check-in. }\end{array}$ & $\begin{array}{l}\text { PDS group antibiotic prescribing } \\
\text { decreased from } 80.0 \% \text { to } 68.3 \% \\
\text { prescribed antibiotics for acute } \\
\text { cough illnesses } \\
\text { CDS group decreased from } 74 \% \text { to } \\
60.7 \% \\
\text { Control group increased slightly } \\
\text { from } 72.5 \% \text { to } 74.3 \% \text {. } \\
\text { The differences for intervention } \\
\text { groups and control (control vs. PDS } \\
\text { P=0.003; control vs. CDS P=0.014) } \\
\text { One third providers in intervention } \\
\text { groups reduced prescribing } 20 \% \\
\text { Difference between intervention } \\
\text { groups } \\
\text { (PDS vs. CDS P=0.67) }\end{array}$ \\
\hline
\end{tabular}




\begin{tabular}{|c|c|c|}
\hline $\begin{array}{l}\text { Study } 4 \\
\text { (McNulty et } \\
\text { al., 2018) }\end{array}$ & $\begin{array}{l}\text { Workshop participants } \\
\text { completed TARGET AMS self- } \\
\text { assessment and a one hour } \\
\text { workshop including the } \\
\text { TARGET PowerPoint } \\
\text { presentation, stress the } \\
\text { advantages to staff and patients } \\
\text { of AMS, evidence around } \\
\text { benefits for or against antibiotics } \\
\text { for common community } \\
\text { infections using national PHE } \\
\text { antibiotic and NICE guidance, } \\
\text { clinical scenarios and antibiotic } \\
\text { prescribing monitoring }\end{array}$ & $\begin{array}{l}6.1 \% \text { lower antibiotic prescribing } \\
\text { rate } \\
11 \% \text { trimethoprim prescribing in the } \\
\text { intervention with TARGET } \\
\text { practices compared to the control. }\end{array}$ \\
\hline $\begin{array}{l}\text { Study } 5 \\
\text { (Légaré et } \\
\text { al., 2010) }\end{array}$ & $\begin{array}{l}\text { Primary outcome was the } \\
\text { proportion of patients who } \\
\text { decided to use antibiotics } \\
\text { immediately after consultation } \\
\text { with providers using } \\
\text { DECISION+ and where shared } \\
\text { decision-making had occurred. } \\
\text { Control group providers were } \\
\text { just given DECISION+ with no } \\
\text { training or workshops. }\end{array}$ & $\begin{array}{l}\text { Experimental group showed } 21 \% \\
\text { fewer patients decided to use } \\
\text { antibiotics immediately } \\
\text { Control group only } 8 \% \text { fewer } \\
\text { patients decided to use antibiotics } \\
\text { Percentage of patients who decided } \\
\text { to use antibiotics after consultation } \\
\text { was } 52.2 \% \text { in the control group and } \\
27.2 \% \text { in the experimental group } \\
\text { (absolute difference } 25.0 \% \text {, adjusted } \\
\text { relative risk } 0.48,95 \% \text { confidence } \\
\text { interval } 0.34-0.68) \text {. } \\
\text { DECISION+ was associated with } \\
\text { patients taking a more active role in } \\
\text { decision-making (Z }=3.9, p< \\
0.001) \text {. Patient outcomes } 2 \text { weeks } \\
\text { after consultation were similar in } \\
\text { both groups. }\end{array}$ \\
\hline
\end{tabular}

